\title{
Engineering Statistics and Data Analysis in Construction Contract Bids
}

\author{
Khalid Abdel Naser Abdel Rahim
}

Department of Civil Engineering, Faculty of Science and Technology, University of Coimbra, Coimbra 3030-790, Portugal

\begin{tabular}{l} 
ARTICLE INFO \\
\hline Keywords: \\
Engineering data analysis \\
Construction management \\
Contract bids \\
Z-test \\
T-test
\end{tabular}

\begin{abstract}
The manuscript will introduce a new engineering statistical and data analysis which are used to evaluate successful construction contract bids. The methods used in the evaluation analysis includes coefficient of correlation (COC), hypothesis testing (Z-test for Estimated Cost, Z-test for \% Mark-up and T-test). The evaluation was conducted on various construction company in accordance to sectors A to D. It has been concluded that the \% mark-up percentage had a minor effect on the win or loss of the contract bid between different sectors. This research has found that (1) the null hypothesis cannot be rejected at the 5\% significance level the samples showed no significant proof to which of the sectors is more successful in winning bids than other, (2) the regression analysis indicated that as the estimated cost increases the \% mark-up decrease for all sectors, (3) the t-test illustrated no significant difference existing between the mean estimated cost and mean \% mark-up between contracts won and contracts lost for all sectors, since the value of t Stat was less than t-critical two tailed the null hypothesis cannot be rejected and (4) there is a stronger correlation existing for the successful bids than unsuccessful.
\end{abstract}

\section{Introduction}

A contractor called Discovery Contracts desired to perform an analysis of their construction contract bids (Mackie et al., 2010). The contractor's data file consisted of a 160 Discovery Contract's bids. The contract bids were divided in to four sectors A, B, C and D and in each sector the contracts was alienated in to either successful or unsuccessful. The set of data was separated into four tables according to the sector, win and loss. Tables 8, 14, 20 and 26 in Appendix 1 to 4 section of this manuscript represents the data for sectors A, B, C and D respectively. The data mainly consisted of the following key information:

- The estimated cost of the project.

- The \% mark-up applied to the estimated cost in order to arrive at the bid price.

- The sector (type of project) from which the contract arose.

- Whether or not the bid was successful.

* Corresponding Author E-Mail Address: Khalid.ar@outlook.com 
The purpose of this venture was to highlight and describe the main characteristics and anomalies in the data, performing general statistical and graphical descriptions and carrying out suitable statistical tests (Vardeman et al., 1994).

The International Federation of Consulting Engineers FIDIC (1999) is the main source of reference for employers to establish the contract conditions for the construction and engineering works. Abu Hammad et al. (2010) carried out a research on the duration and cost of public building construction projects using statistical analysis and simulations. Moreover, Bakhshi et al. (2012) proposed and validated cost correlation calculation method between construction projects. In addition, Bilal et al. (2016) presented a state of art review on the current status, prospects and forthcoming trends of huge data in the construction sector. Furthermore, Thomas et al. (2003) stated ten simple aspects for the selection of subcontractors in the construction projects. On the other hand, Ugochukwu (2013) evaluated the suitability of contractors by focusing on the duration of the tending process in public building projects in Nigeria.

\section{Information Breakdown}

The first stage of the analysis was to identify useful summations which could be extracted from the data provided (Miller and Freund et al., 1965). The summations would include answers to questions, such as, what percentage of the contracts were won or lost, which sector the bids were most successful in, is there any substantial dissimilarity flanked by the mean percentage mark-up among contracts won and contracts lost, is there any considerable variation between the estimated cost flanked by contracts won and contracts lost, is there a relationship between the estimated cost and the \% mark-up and do these questions differ whatsoever from one sector to another (Metcalfr et al., 1997).

\section{Analysis and Results}

The first and most basic piece of information to be determined as part of highlighting the key features of data was the percentage of contracts won and lost by Discovery Contracts. Initially, the data was sorted according to successful and unsuccessful contracts and from that it was found that the Discovery Contracts had 45 winning contracts and 115 lost contracts. Thus, the percentage of contracts won was $28 \%$ of total bids, more than one quarter of contracts was successful and the percentage of contracts lost was 72\% as revealed in Figure 1 and Figure 2 (a).

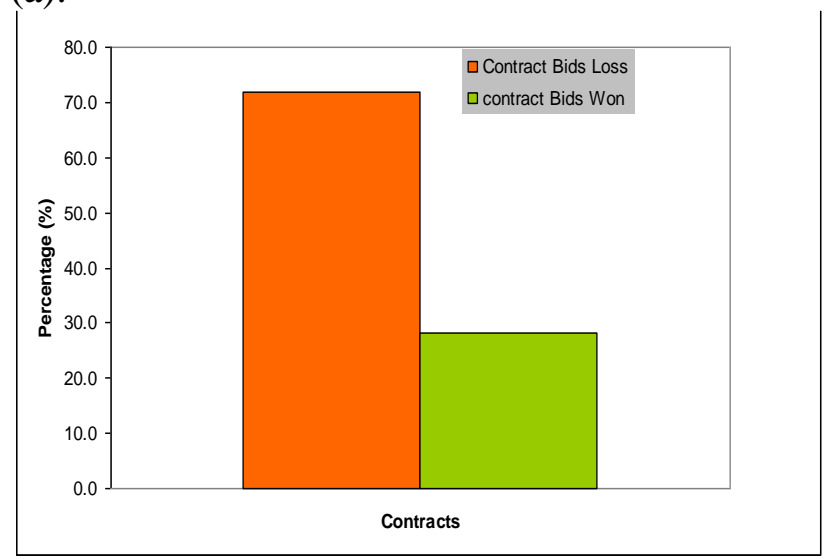

Figure 1. Overall percentage of bids won and loss 
Table 1 demonstrates the total number of bids for each sector and number of win and loss contracts. For instance, sector A had 39 bids by which, only 13 bids were successful and 26 unsuccessful bids.

Table 1.

The number of win, loss and total for each sector

\begin{tabular}{cccc}
\hline Sector & Win & Loss & Total \\
\hline A & 13 & 26 & 39 \\
B & 13 & 24 & 37 \\
C & 8 & 33 & 41 \\
D & 11 & 32 & 43 \\
Overall & 45 & 115 & 160 \\
\hline
\end{tabular}

The next step to be determined was if Discovery Contracts was more successful at winning contracts in some sectors than in others and the percentage of contracts bids the company has done for all sectors. As presented in Figure 2 (b), there was only a minor discrimination between the division of sectors with only a $4 \%$ difference between the least and greatest sector percentages. This indicates that Discovery Contracts does not focus or prefer a certain sector on the other. Moreover, the company was more successful at winning bids in sectors A and B with a $29 \%$ of contracts won for each compared with sectors C and D which they had only $18 \%$ and $24 \%$ of contracts won respectively as described in Figure 2 (c). On the other hand, sector B had the least percentage of contracts lost with $21 \%$ and sector C and sector D had the highest with $28 \%$ for each of them as presented in figure $2(\mathrm{~d})$.

After determining the success rate for each sector (Figure 3 ) it was observed that sector B had the greatest success with an amount of 36. Therefore, there is one winning bid for every 2.85 tenders. Conversely, sector $\mathrm{C}$ had the lowest amount with a value of 19 , which indicates that there is one winning bid for every 5.13 tenders.
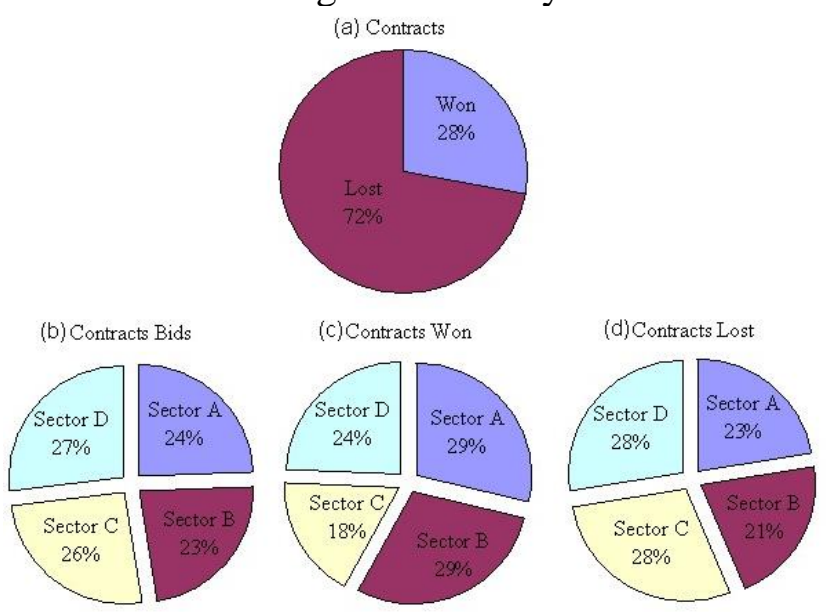

Figure 2. Highlight of the main features of the data being (a) percentage of contracts win and loss; (b) percentage of contract bids for each sector; (c) percentage of contracts won for each sector and (d) percentage of contracts loss for each sector 


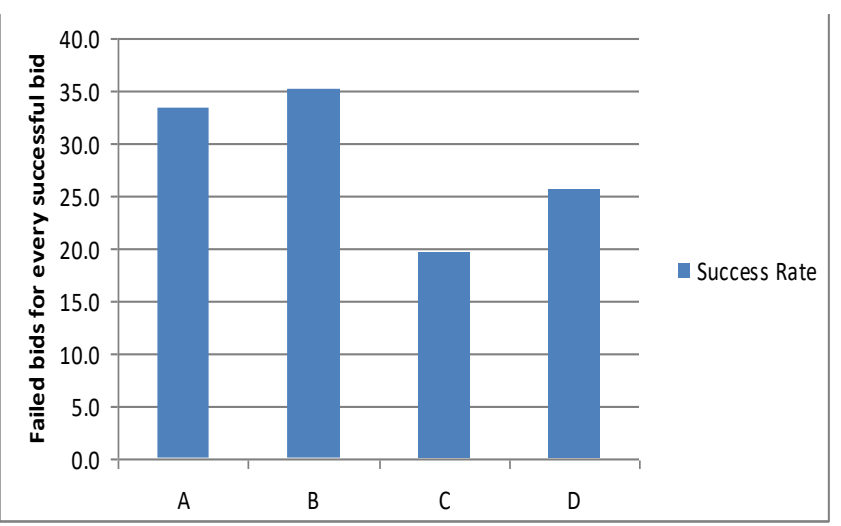

Figure 3. Success rate for each sector

Table 2.

Comparing sectors to obtain $p, 1-p$ and $z$ values

\begin{tabular}{ccccc}
\hline Sectors compared & $\mathbf{p}$ & $\mathbf{1 - p}$ & $\mathbf{Z}$ & $\mathbf{Z}$ critical \\
\hline A vs. B & 0.3171 & 0.6829 & -0.1749 & 1.9600 \\
A vs. C & 0.2625 & 0.7375 & 1.4022 & 1.9600 \\
A vs. D & 0.3158 & 0.6842 & 0.7218 & 1.9600 \\
B vs.C & 0.2500 & 0.7500 & 1.6505 & 1.9600 \\
B Vs.D & 0.3000 & 0.7000 & 0.9245 & 1.9600 \\
C Vs.D & 0.2436 & 0.7564 & -0.6267 & 1.9600 \\
\hline
\end{tabular}

A comparison has been made as presented in table 2 to find the $\mathrm{z}$ value. For all cases of comparison the value of $\mathrm{z}$ is less than the $\mathrm{z}$ critical (1.96). Therefore, the null hypothesis cannot be rejected at the $5 \%$ significance level the samples showed no significant proof to which of the sectors is more successful in winning bids than other. With respect to the success rate in figure 3 a judgment can be made that sectors A and B is more successful in winning contracts than sectors $\mathrm{C}$ and $\mathrm{D}$.

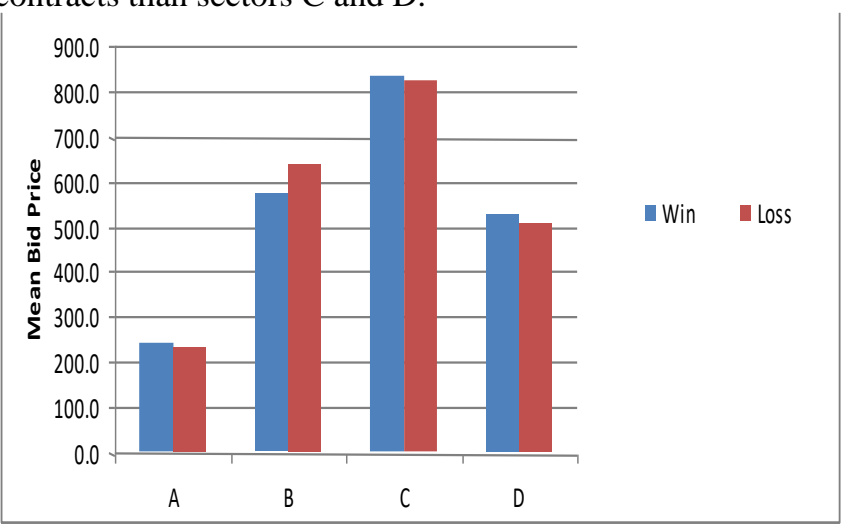

Figure 4. Mean bid price win and loss for all sectors

A histogram of mean bid price win and loss has been carried as shown is figure 4 . Though there is a minor difference in the mean bid price values for win and loss contracts, the data somehow shows symmetry for both win and loss contracts. The symmetry is clearly view at the middle (sector $\mathrm{C}$ ). The mean bid price starts at sector $\mathrm{A}$ with the minimum mean and going up to maximum value at sector $\mathrm{C}$ and starts to go down again at sector $\mathrm{D}$. 


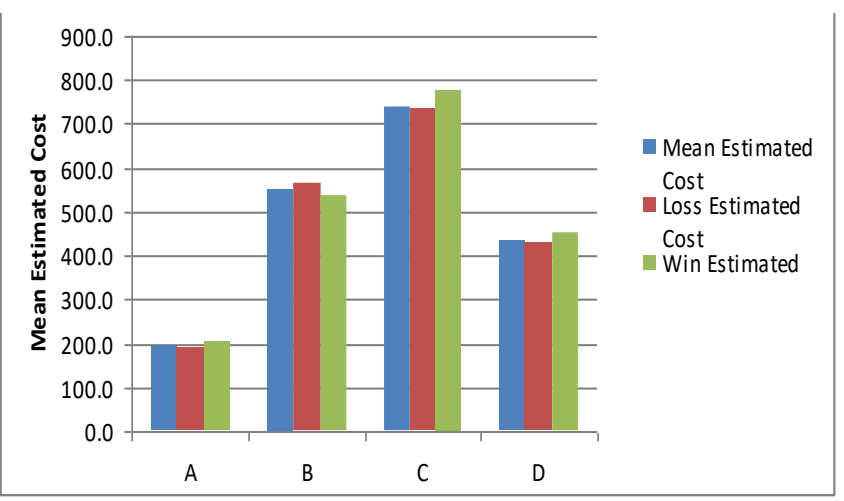

Figure 5. Mean estimated cost for all sectors

Again, symmetry occurs for the mean, loss and won estimated cost as illustrated in figure 5 . The highest mean estimated cost was for sector C, while lower was for sector A. Additionally, the same situation was for loss estimated cost and win estimated cost with the highest mean being in sector $\mathrm{C}$ and lowest in sector A.

For the mean \% mark-up the case was different from that for mean estimated cost, for instance, sector A had the highest mean \% mark-up, mean loss and mean win compared with other sectors. On the other hand, sector $\mathrm{C}$ had the lowest means for $\%$ mark-up, loss and win. In addition, the mean loss seem to be slightly higher than mean win for sectors A, C, D and similar in sector B (Figure 6).

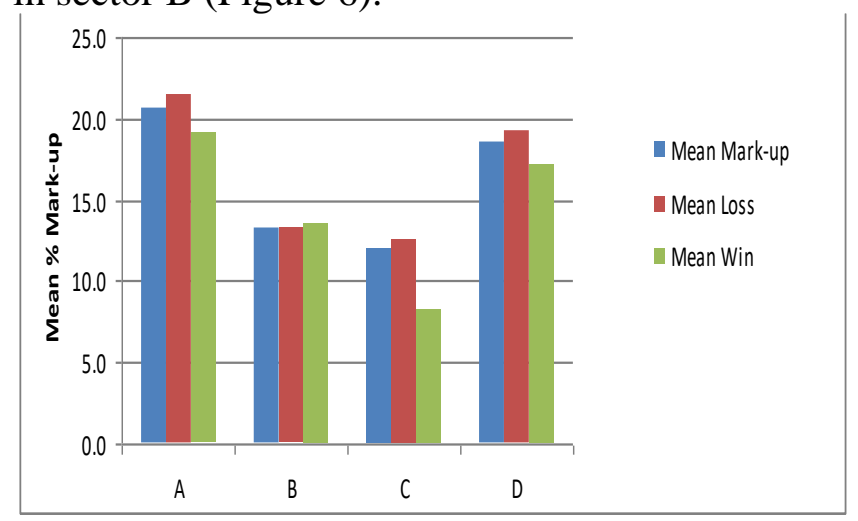

Figure 6. Mean \% mark-up for all sectors

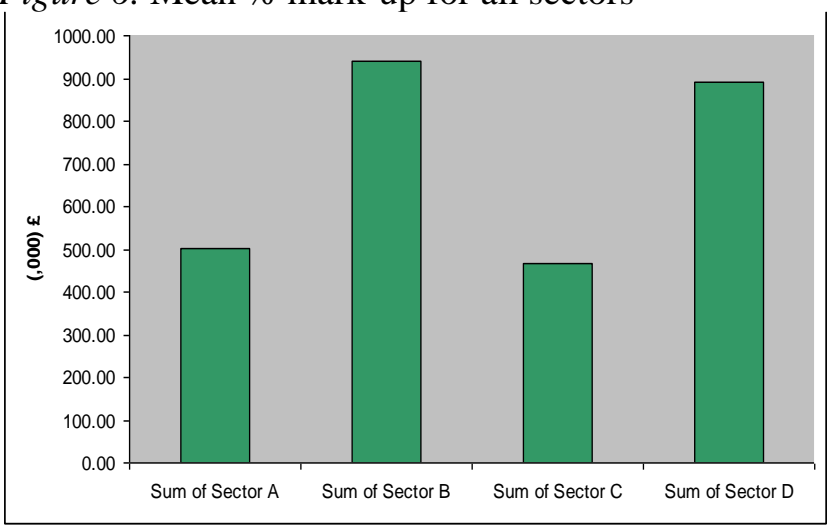

Figure 7. Sum of win for each sector

Although there is a slightly small difference in the sum of win between sector B and sector D (about $£ 47.1$ ) sector B had the highest sum of win with an amount of £939. Alternatively, 
sector $\mathrm{C}$ had the lowest sum of win with an amount of $£ 465.5$. By comparing the sum of win for sector $\mathrm{A}$ with that for sector $\mathrm{C}$, the difference is again minor (approximately £36.8). Generally, sectors B and D has higher sum of win than sectors A and C as demonstrated in figure 7.

\section{Inferential Statistics}

\subsection{Coefficient of Correlation}

Estimated Cost vs. \% Mark-up using overall correlation to find the linear relationship between estimated cost and \% mark-up using equation 1, 2, 3 and 4 respectively.

$$
\begin{aligned}
S_{x y} & =\sum x_{i} y_{i}-\frac{\sum x_{i} \sum y_{i}}{n}= \\
1108644-\frac{77192.6 x 2589.6}{160}=-140718.231 & \\
S_{x x}= & \sum x_{i}^{2}-\frac{\left(\sum x_{i}\right)^{2}}{n}= \\
45221877-\frac{77192.6^{2}}{160} & =7980017.658 \\
S_{y y} & =\sum y_{i}^{2}-\frac{\left(\sum y_{i}\right)^{2}}{n}= \\
46761.81-\frac{2589.6^{2}}{160} & =4849.134 \\
r & =\frac{-140718.231}{\sqrt{7980017.658 x 4849.134}}=-0.715
\end{aligned}
$$

An $r$ value of -0.715 indicates that there is a strong negative correlation between the estimated cost of the tenders and the \% mark-up. This demonstrates that as the estimated cost increases the $\%$ mark-up decreases. Moreover, figure 8 visually represents the value of $\mathrm{R}^{2}$, which is 0.5118 and $y=-0.0176 x+24.693$. In addition, the regression has been carried out for each sector and is presented in (Appendix) figures 11, 14, 17 and 20 with respect to sector $\mathrm{A}, \mathrm{B}, \mathrm{C}$ and D. Although the case is similar for sectors A, B, C and D to that of the overall regression as the estimated cost increases the \% mark-up decreases, each of the regression plots carried out for sectors had different slope. For example, sector $\mathrm{C}$ had the steeper slope with $\mathrm{y}=-0.0204 \mathrm{x}+$ 27.054 and $R^{2}$ value of 0.3322 . Alternatively, sector $A$ had the gentlest slope with $y=-0.0289 x$ +26.354 and $R^{2}$ value of 0.1515 .

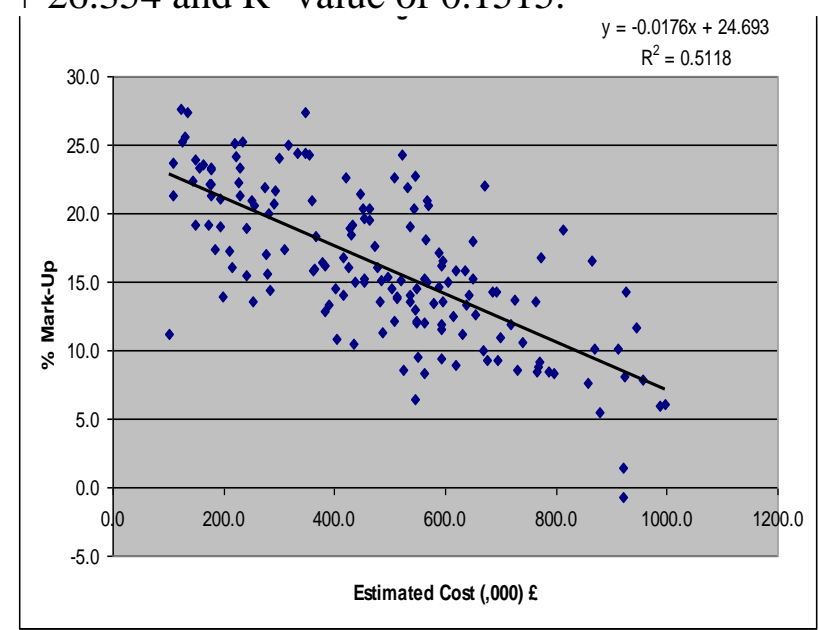

Figure 8. Overall regression chart plot estimated cost vs. \% mark-up 
Table 3 ( $a$ and $b$ ) shows the overall regression analysis, while, Table 4 presents the correlation coefficient for each sector and overall. The correlation analysis was carried out between the estimated cost and the \% mark-up. It was found that sector $\mathrm{A}$ has the highest correlation coefficient with a value of -0.38924 and sector $C$ has the lowest with a value of -0.57635 . Generally speaking, the correlation coefficient values for all sector as well as for overall is fairly low.

Table 3.

Overall regression table being (a) summary output and (b) Anova

(a) SUMMARY OUPUT

\begin{tabular}{ll}
\hline Regression Statistics & \\
\hline Multiple R & 0.715395408 \\
R Square & 0.51179059 \\
Adjusted R Square & 0.508700657 \\
Standard Error & 3.870705952 \\
Observations & 160 \\
\hline
\end{tabular}

(b) ANOVA

\begin{tabular}{llllll}
\hline & $d f$ & $S S$ & $M S$ & $F$ & Significance $F$ \\
\hline Regression & 1 & 2481.553 & 2481.553 & 165.6316 & $2.21162 \mathrm{E}-26$ \\
Residual & 158 & 2367.213 & 14.98236 & & \\
Total & 159 & 4848.766 & & & \\
\hline
\end{tabular}

Table 3. (b) ANOVA continuation

\begin{tabular}{|c|c|c|c|c|c|c|c|c|}
\hline & Coefficients & Standard Error & t Stat & P-value & Lower $95 \%$ & Upper $95 \%$ & Lower $95.0 \%$ & Upper $95.0 \%$ \\
\hline Intercept & 24.69281097 & 0.728452865 & 33.89760981 & $2.16974 \mathrm{E}-74$ & 23.25404952 & 26.13157243 & 23.25404952 & 26.13157243 \\
\hline X Variable 1 & -0.017634322 & 0.00137021 & -12.86979469 & $2.21162 \mathrm{E}-26$ & -0.020340613 & -0.014928031 & -0.020340613 & -0.014928031 \\
\hline
\end{tabular}

Table 4.

Estimated cost vs. \% mark-up correlation for each sector and overall

\begin{tabular}{ll}
\hline Estimated Cost vs. \% & Mark-Up Correlation \\
\hline Sector & Correlation Coefficient \\
\hline A & -0.38924 \\
B & -0.45908 \\
C & -0.57635 \\
D & -0.41617 \\
Overall & -0.7154 \\
\hline
\end{tabular}

\subsection{Hypothesis Testing}

\subsubsection{Z-test for Estimated Cost}

Hypothesis:

- H0: No difference exists between the mean estimated cost between contracts won and contracts lost. 
- Ha: A difference exists between the mean estimated cost between contracts won and contracts lost.

Rejection Criteria: From the z-distribution table, Alpha. 0.5, $z_{a / 2}=1.96$, the $\mathrm{z}$ value is calculated using equation (5).

$$
\begin{aligned}
& \frac{(465.2-489.2)}{\sqrt{\frac{210^{2}}{45}+\frac{230^{2}}{115}}}=-0.632 \\
& z<z_{0.05}=1.96 \\
& -0.632<1.96
\end{aligned}
$$

The value of $\mathrm{z}$ is less than $\mathrm{z}$ critical value which is 1.96 .

Thus, at the 5\% significance level the samples show no significant difference and so the null hypothesis cannot be rejected.

\subsubsection{Z-test for \% Mark-up}

Hypothesis:

- H0: No difference exists between the mean \% mark-up between contracts won and contracts lost.

- Ha: A difference exists between the mean \% mark-up between contracts won and contracts lost.

Rejection Criteria: From the z-distribution table, Alpha. 0.5, $z_{a / 2}=1.96$

The value of $\mathrm{z}$ (Table 5) is less than the $\mathrm{z}$ critical value (1.96). Therefore, at the 5\%

\begin{tabular}{|c|c|c|}
\hline \multicolumn{3}{|l|}{ \% Mark-up } \\
\hline & Variable 1 & Variable 2 \\
\hline Mean & 15.07912315 & 16.61783275 \\
\hline Known Variance & 45 & 115 \\
\hline Observations & 45 & 115 \\
\hline Hypothesized Mean Difference & 0 & \\
\hline $\mathrm{z}$ & -1.088031993 & \\
\hline $\mathrm{P}(\mathrm{Z}<=\mathrm{z})$ one-tail & 0.138290492 & \\
\hline z Critical one-tail & 1.644853627 & \\
\hline $\mathrm{P}(\mathrm{Z}<=\mathrm{z})$ two-tail & 0.276580984 & \\
\hline z Critical two-tail & 1.959963985 & \\
\hline
\end{tabular}
significance level the samples demonstrate no significant difference and so cannot reject the null hypothesis.

Table 5.

$z<z_{0.05}=1.96$ 
Table 6.

Summary of t-test results (Estimated cost and \% mark-up) for each sector

\begin{tabular}{|c|c|c|c|c|}
\hline \multirow{2}{*}{ Sector } & \multicolumn{2}{|c|}{ Estimated Cost t-tests } & \multicolumn{2}{c|}{ \% Mark-Up t-tests } \\
\cline { 2 - 5 } & t-test Stat & t Critical two-tail & t-test Stat & t Critical two-tail \\
\hline A & 0.70257882726742 & 2.05953853565859 & -1.65939751630777 & 2.08596344129554 \\
\hline B & -0.7720545303928 & 2.03951343844151 & 0.478610911459202 & 2.03010791544831 \\
\hline C & 0.237640727563404 & 2.17881282716507 & -2.08086179260983 & 2.26215715817358 \\
\hline D & 1.95630650593535 & 2.10092203686118 & -1.68096220521439 & 2.07387305831561 \\
\hline
\end{tabular}

Since all $\boldsymbol{t}$ Stat values (Table 6) are less than the t critical two-tail value at the 5\% significance level there is no statistical difference existing. Thus, the null hypothesis cannot be rejected for win and loss in all sectors.

$-1.088<1.96$

\subsubsection{T-test}

Hypothesis:

- H0: No difference exists between the mean \% mark-up between contracts won and contracts lost for each sector.

- Ha: There is a difference between the mean \% mark-up between contracts won and contracts lost for each sector.

\subsubsection{Further Analysis}

Figures 9 and 10 illustrates the \% Mark-up vs. sector of successful and unsuccessful bids.

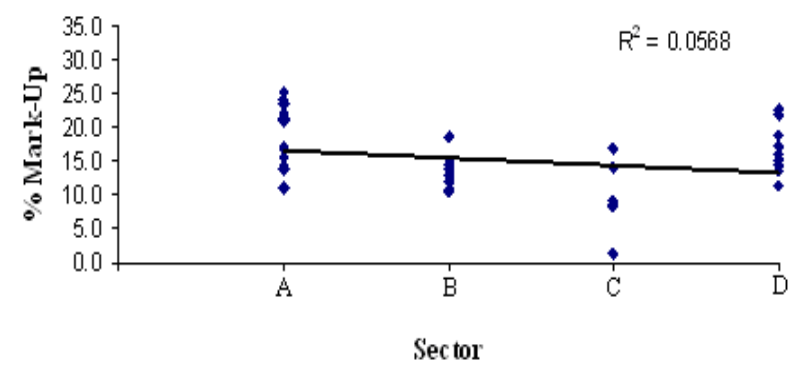

Figure 9. \% Mark-up vs. sector of successful bids

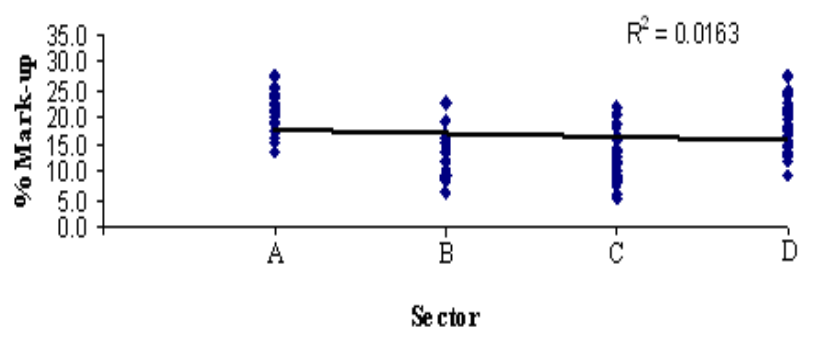

Figure 10. \% Mark-up vs. sector of unsuccessful bids 


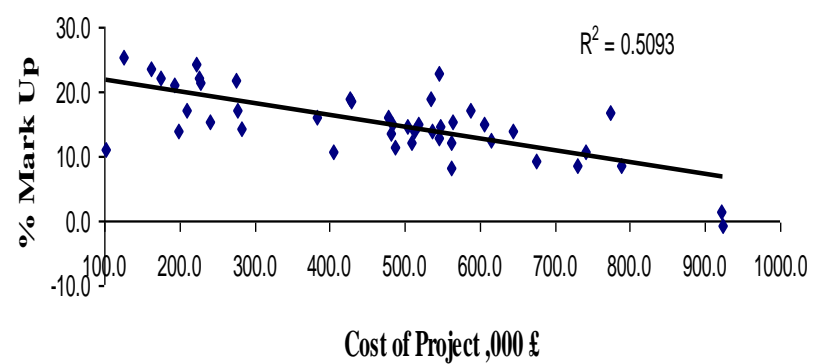

Figure 11. \% Mark-up vs. project cost of successful bids

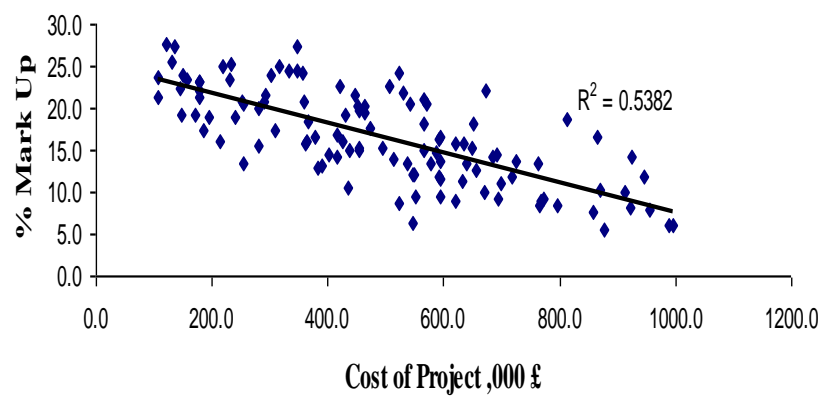

Figure 12. \% Mark-up vs. project cost of unsuccessful bids

After plotting the cost of the project against the \% mark-up for the contracts won or contracts lost as revealed in Figures 11 and 12 it seem that there is a stronger correlation existing for the successful bids.

Finally, after plotting the estimated cost of the project bids for each sector it seem that for both successful and unsuccessful bids as shown in Figures 13 and 14, a strong correlation exists with $\mathrm{R}^{2}$ of greater than 0.32 .

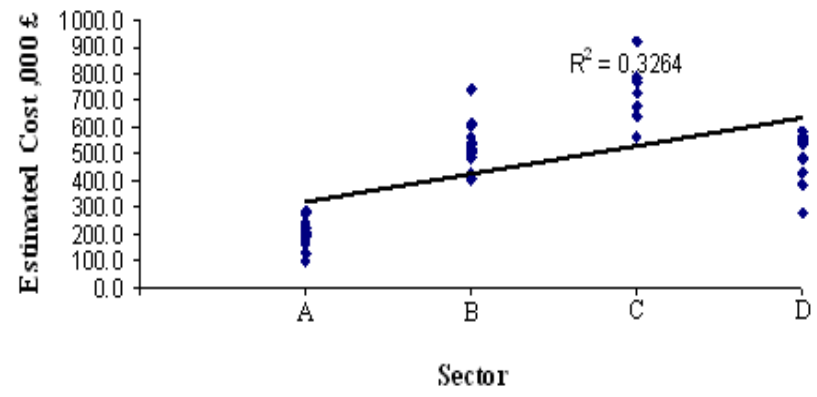

Figure 13. Project cost for each sector of successful bids

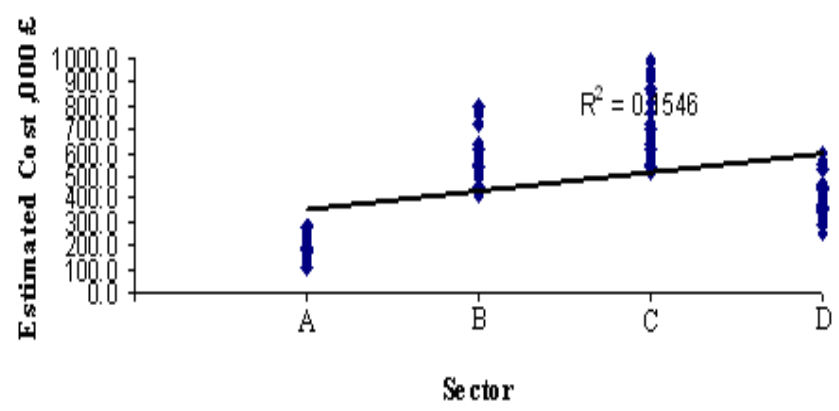

Figure 14. Project cost for each sector of unsuccessful bids 


\section{Conclusions}

In the conclusion the \% mark-up percentage had a minor effect on the win or loss of the contract bid between different sectors. The various hypothesis testing carried out showed no variation which, could be used by Discovery Contracts to assist in improving the success rates. This was corroborated by the inferential statistics at the 5\% significance level. According to results of various hypothesis tests (Analysis shown in Appendix 1 to 4, Figures 15 to 26 and Tables 7 to 30 for sector $\mathrm{A}, \mathrm{B}, \mathrm{C}$ and $\mathrm{D}$ respectively) carried out the following has been concluded:

- Sector B had the highest success rate of winning bids among all other sectors and sectors A and $\mathrm{B}$ is more successful in winning contracts than sectors $\mathrm{C}$ and $\mathrm{D}$.

- The null hypothesis cannot be rejected at the 5\% significance level the samples showed no significant proof to which of the sectors is more successful in winning bids than other.

- The regression analysis indicated that as the estimated cost increases the \% mark-up decrease for all sectors.

- The regression plot diagram showed that sector $C$ had the steeper slope of $y=-0.0204 x+$ 27.054 and $\mathrm{R}^{2}$ value of 0.3322 compared with regression plot diagram for other sectors.

- The correlation coefficient values for all sector as well as for overall was fairly low.

- The z-test showed no difference existing between the mean estimated cost and mean \% mark-up between contracts won and contracts lost since the value of $\mathrm{z}$ was less than $\mathrm{z}$-critical (1.96) the null hypothesis can not be rejected at the $5 \%$ significance level.

- The t-test illustrated no significant difference existing between the mean estimated cost and mean $\%$ mark-up between contracts won and contracts lost for all sectors, since the value of $t$ Stat was less than $\mathrm{t}$-critical two tailed the null hypothesis can not be rejected.

- There is a stronger correlation existing for the successful bids than unsuccessful.

Finally, more highlight of the differences may be established by refining the level but findings would show insignificant.

\section{References}

Abu Hammad, A. et al, Statistical Analysis on the Cost and Duration of Public Building Projects, Journal of Management in Engineering, Vol. 26, No. 2, April 1, 2010, pp. 105-112.

Bakhshi, P. et al, A method for calculating cost correlation among construction projects in a portfolio, International Journal of Architecture, Engineering and Construction, Vol 1, No 3, September 2012, pp. 134-141.

Bilal, M., Big Data in the construction industry: A review of present status, opportunities, and future trends, Advanced Engineering Informatics 30 (2016) 500-521.

International Federation of Consulting Engineers FIDIC, (1999), Con-ditions of contract for construction for building and engineering works designed by the employer, FIDIC, Geneva.

Mackie, I. et al. (2010) Statistics. Lecture Notes 1, 2, 3 and case study, Research Methods and Communications. University of Dundee.

Metcalfr, A. V. et al. (1997). Statistics in civil engineering. London, New York: Arnold; Wiley.

Miller, I. \& Freund, J. E. et al. (1965). Probability and statistics for engineers. Englewood Cliffs, N.J.,: Prentice-Hall.

Thomas, Ng. et al, Ten Basic Factors to Identify Suitable Subcontractors for Construction Projects, CIB TG 23 International Conference, October 2003, pp. 1-8, Hong Kong. 
Ugochukwu, S. C., Evaluation of the Adequacy of Contractors' Tendering Duration for Public Building Projects in Nigeria, The International Journal Of Engineering And Science (IJES), Vol. 2, Issue 9, 2013, pp. 16-25.

Vardeman, S. B. et al. (1994). Statistics for engineering problem solving. Boston: PWS Pub. Co. 


\section{Appendix}

The appendix shows the classifications of the bids according to sector and contract won or not. Moreover, the appendix includes some general descriptions of the data, interpretation and main features for each sector.

\section{Appendix 1 (Sector A)}

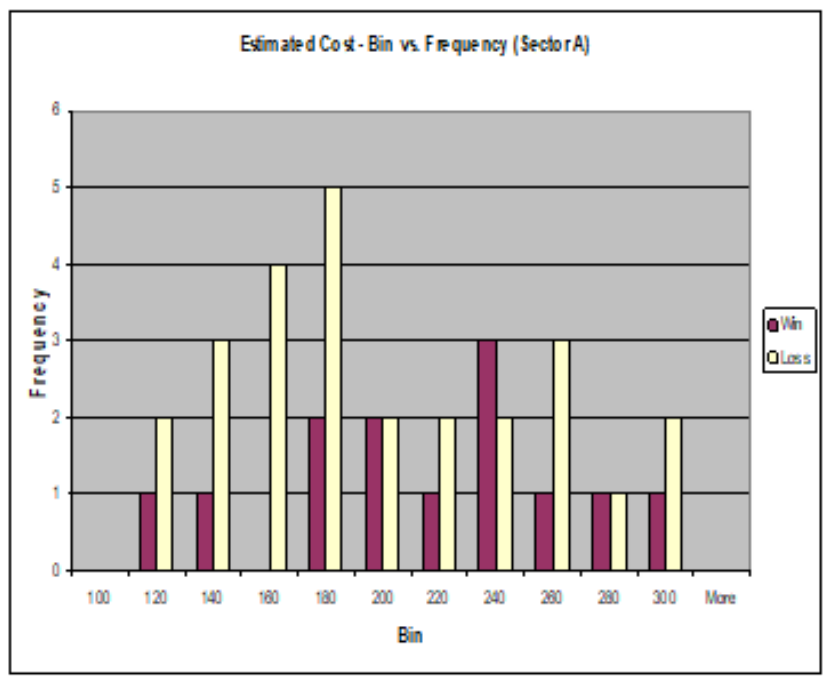

Figure 15. Estimated cost - bin vs. frequency (sector A)

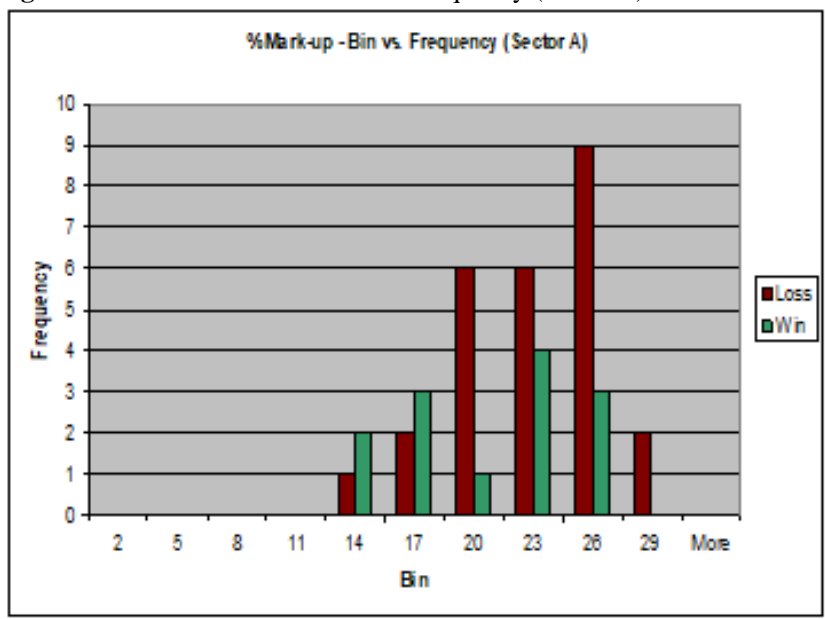

Figure 16. \% mark-up - bin vs. frequency (sector A)

Table 7. Set of data for sector A sorted according to contracts won and contracts loss

\begin{tabular}{|c|c|c|c|c|c|c|c|c|c|c|c|}
\hline $\begin{array}{c}\text { Bid } \\
\#\end{array}$ & $\begin{array}{c}\text { Estimated } \\
\text { Cost }\end{array}$ & $\begin{array}{c}\% \\
\text { Mark-up }\end{array}$ & Sector & $\begin{array}{l}\text { Contract } \\
\text { Won? }\end{array}$ & $\begin{array}{c}\text { Bid } \\
\text { Price }\end{array}$ & $\begin{array}{c}\text { Bid } \\
\#\end{array}$ & $\begin{array}{c}\text { Estimated } \\
\text { Cost }\end{array}$ & $\begin{array}{c}\% \\
\text { Mark-up }\end{array}$ & Sector & $\begin{array}{c}\text { Contract } \\
\text { Won? }\end{array}$ & Bid Price \\
\hline 9 & 101.3 & 11.2 & A & yes & 112.7 & 63 & 218.6 & 25.1 & A & no & 273.5 \\
\hline 13 & 222.0 & 24.1 & A & yes & 275.5 & 66 & 144.1 & 22.4 & A & no & 176.5 \\
\hline 25 & 241.3 & 15.4 & A & yes & 278.5 & 68 & 281.5 & 20.0 & A & no & 337.7 \\
\hline 27 & 126.2 & 25.3 & A & yes & 158.1 & 72 & 232.9 & 25.2 & A & no & 291.5 \\
\hline 50 & 228.2 & 21.3 & A & yes & 276.7 & 79 & 107.7 & 23.6 & A & no & 133.2 \\
\hline 53 & 199.4 & 14.0 & A & yes & 227.3 & 90 & 185.3 & 17.4 & A & no & 217.5 \\
\hline 78 & 226.4 & 22.2 & A & yes & 276.7 & 96 & 279.4 & 15.6 & A & no & 323.1 \\
\hline 94 & 209.7 & 17.2 & A & yes & 245.8 & 103 & 130.6 & 25.6 & A & no & 164.0 \\
\hline
\end{tabular}




\begin{tabular}{|c|c|c|c|c|c|c|c|c|c|c|c|}
\hline 106 & 162.2 & 23.5 & A & yes & 200.4 & 110 & 254.3 & 20.6 & A & no & 306.6 \\
\hline 135 & 277.1 & 17.0 & A & yes & 324.1 & 111 & 194.2 & 19.0 & A & no & 231.2 \\
\hline 145 & 175.5 & 22.2 & A & yes & 214.3 & 121 & 172.0 & 19.2 & A & no & 205.1 \\
\hline 150 & 193.7 & 21.1 & A & yes & 234.5 & 123 & 241.1 & 18.9 & A & no & 286.7 \\
\hline 157 & 282.4 & 14.4 & A & yes & 323.0 & 126 & 289.6 & 20.7 & A & no & 349.5 \\
\hline 8 & 156.2 & 23.3 & A & no & 192.7 & 136 & 177.3 & 21.3 & A & no & 215.1 \\
\hline 16 & 108.1 & 21.4 & A & no & 131.1 & 141 & 149.5 & 24.0 & A & no & 185.4 \\
\hline 21 & 229.4 & 23.4 & A & no & 283.0 & 148 & 214.9 & 16.1 & A & no & 249.5 \\
\hline 30 & 134.5 & 27.4 & A & no & 171.3 & 154 & 148.4 & 19.1 & A & no & 176.8 \\
\hline 41 & 177.8 & 23.2 & A & no & 219.1 & 158 & 178.3 & 23.3 & A & no & 219.8 \\
\hline 42 & 177.7 & 22.1 & A & no & 217.1 & 159 & 121.9 & 27.6 & A & no & 155.6 \\
\hline 51 & 253.7 & 13.5 & A & no & 288.0 & & & & & & \\
\hline
\end{tabular}

Table 8. Summary of properties of data for sector $A$

\begin{tabular}{|c|c|c|c|}
\hline Sector A & Estimated Cost & \%Mark Up & Bid Price \\
\hline Mean & 195 & 20.7 & 234.6 \\
\hline Std_dev & 53.6082 & 3.983031 & 61.69315 \\
\hline Minimum & 101.3 & 11.2 & 112.7 \\
\hline Maximum & 289.6 & 27.6 & 349.5 \\
\hline Number & 39 & 39 & 39 \\
\hline Confidence & 16.82468774 & 1.250056 & 6.663157 \\
\hline \% Pass Rate & 33.333 & 33.333 & 33.333 \\
\hline Std_dev & 2873.839107 & 15.864536 & 3806.045 \\
\hline Number Won & 13 & 13 & 13 \\
\hline
\end{tabular}

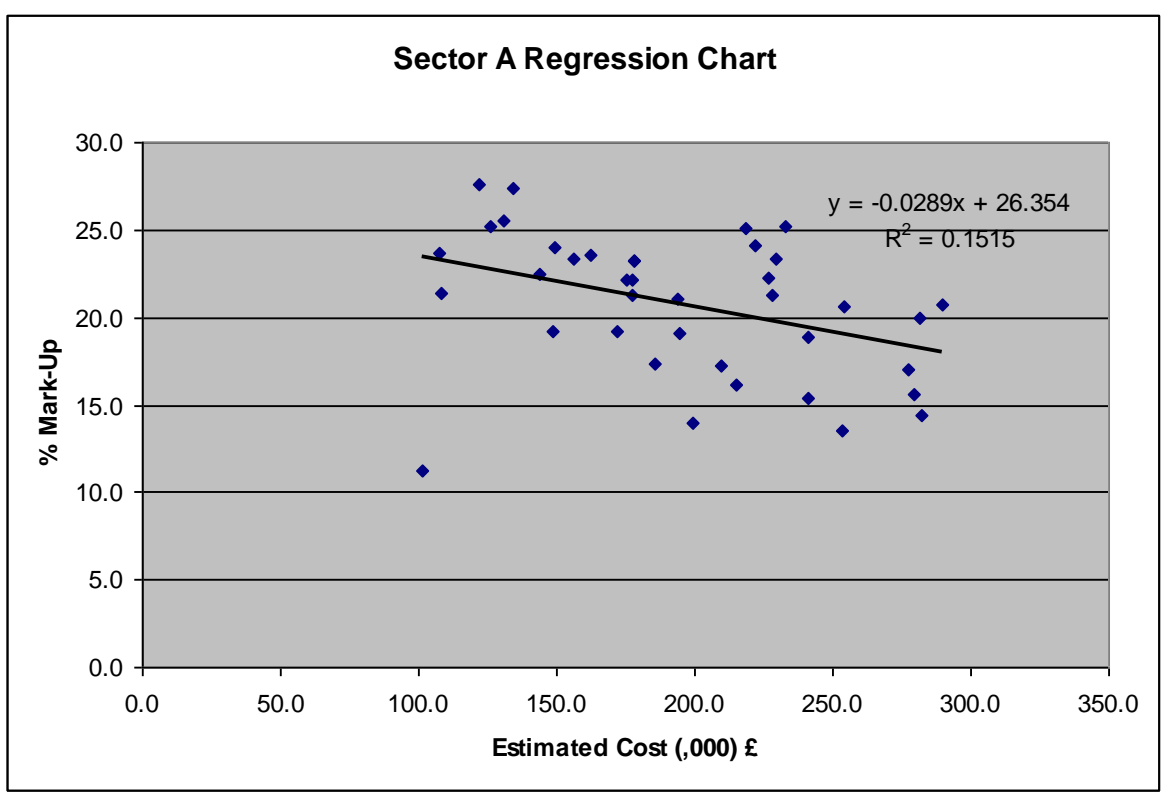

Figure 17. Sector A regression chart plot Estimated cost vs. \% mark-up 
Table 9. Summary of data properties (win and loss) for sector A

\begin{tabular}{|c|c|c|c|c|c|c|}
\hline \multirow{2}{*}{ Sector A } & \multicolumn{3}{|c|}{ Win } & \multicolumn{3}{|c|}{ Loss } \\
\hline & Estimated Cost & $\%$ Mark-up & Bid price & Estimated Cost & $\%$ Mark-up & Bid price \\
\hline Bids & \multicolumn{3}{|c|}{13} & \multicolumn{3}{|c|}{26} \\
\hline Mean & 203.5 & 19.1 & 242.1 & 190.7 & 21.5 & 230.8 \\
\hline St_dev & 52.92038562 & 4.492453316 & 61.05032814 & 54.47538635 & 3.533592837 & 62.86193146 \\
\hline St_dev ${ }^{2}$ & 2800.567214 & 20.1821368 & 3727.142566 & 2967.567718 & 12.48627834 & 3951.622427 \\
\hline$t_{\alpha / 2}$ & \multicolumn{3}{|c|}{2.178812827} & \multicolumn{3}{|c|}{2.059538536} \\
\hline Confidence & 28.76732071 & 2.442080567 & 33.18672659 & 20.9392796 & 1.358244399 & 24.16290452 \\
\hline Lower & 174.7 & 16.7 & 208.9 & 169.8 & 20.1 & 206.6 \\
\hline Upper & 232.3 & 21.6 & 275.3 & 211.7 & 22.9 & 255 \\
\hline Interval & $(174.7,232.3)$ & $(16.7,21.6)$ & $(208.9,275.3)$ & $(169.8,211.7)$ & $(20.1,22.9)$ & $(206.6,255)$ \\
\hline
\end{tabular}

Table 10. Sector A regression table being (a) summary output and (b) Anova

(a)

\section{SUMMARRY OUTPUT}

\begin{tabular}{cc}
\hline \multicolumn{2}{c}{ Regression Statistics } \\
\hline Multiple R & 0.389242172 \\
R Square & 0.151509468 \\
Adjusted R Square & 0.128577292 \\
Standard Error & 3.718160403 \\
Observations & 39 \\
\hline
\end{tabular}

(b)

ANOVA

\begin{tabular}{cccccc}
\hline & $d f$ & $S S$ & $M S$ & $F$ & Significance $F$ \\
\hline Regression & 1 & 91.33784089 & 91.33784089 & 6.606850781 & 0.014318021 \\
Residual & 37 & 511.5145211 & 13.82471679 & & \\
Total & 38 & 602.852362 & & & \\
\hline
\end{tabular}

\begin{tabular}{ccccccccc}
\hline & Coefficients & Standard Error & $t$ Stat & P-value & Lower 95\% & Upper 95\% & Lower 95.0\% & Upper 95.0\% \\
\hline Intercept & 26.3538547 & 2.273231705 & 11.59312297 & $7.03401 \mathrm{E}-14$ & 21.74784979 & 30.95985961 & 21.74784979 & 30.95985961 \\
X Variable 1 & -0.02892027 & 0.011251362 & -2.570379501 & 0.014318021 & -0.051717695 & -0.006122846 & -0.051717695 & -0.006122846 \\
\hline
\end{tabular}

Table 11. t-test estimated cost - sector $A$ estimate win and loss

\section{Estimated cost}

\section{Estimate A: Win loss}

t-Test: Two-Sample Assuming Unequal Variances

\begin{tabular}{ccc}
\hline & Variable 1 & Variable 2 \\
\hline Mean & 203.490855 & 190.7362825 \\
Variance & 2800.567214 & 2967.567718
\end{tabular}


Observations

Hypothesized Mean Difference

df

t Stat

$\mathrm{P}(\mathrm{T}<=\mathrm{t})$ one-tail

t Critical one-tail

$\mathrm{P}(\mathrm{T}<=\mathrm{t})$ two-tail

t Critical two-tail
13

0

25

0.702578827

0.244404585

1.708140745

0.48880917

2.059538536

Table 12. t-test \% mark-up - sector A estimate win and loss

\section{$\%$ Mark-up}

Estimate A: Win Loss

t-Test: Two-Sample Assuming Unequal Variances

\begin{tabular}{|c|c|c|}
\hline & Variable 1 & Variable 2 \\
\hline Mean & 19.13751649 & 21.50337368 \\
\hline Variance & 20.1821368 & 12.48627834 \\
\hline Observations & 13 & 26 \\
\hline Hypothesized Mean Difference & 0 & \\
\hline $\mathrm{df}$ & 20 & \\
\hline t Stat & -1.659397516 & \\
\hline $\mathrm{P}(\mathrm{T}<=\mathrm{t})$ one-tail & 0.056317891 & \\
\hline t Critical one-tail & 1.724718218 & \\
\hline $\mathrm{P}(\mathrm{T}<=\mathrm{t})$ two-tail & 0.112635782 & \\
\hline t Critical two-tail & 2.085963441 & \\
\hline
\end{tabular}

\section{Appendix 2 (Sector B)}

Table 13. Set of data for sector B sorted according to contracts won and contracts loss

\begin{tabular}{|c|c|c|c|c|c|c|c|c|c|c|c|}
\hline $\begin{array}{c}\text { Bid } \\
\#\end{array}$ & Estimated Cost & $\begin{array}{c}\% \\
\text { Mark-up }\end{array}$ & Sector & $\begin{array}{c}\text { Contract } \\
\text { Won? }\end{array}$ & Bid Price & $\begin{array}{c}\text { Bid } \\
\#\end{array}$ & $\begin{array}{c}\text { Estimated } \\
\text { Cost }\end{array}$ & $\begin{array}{c}\% \\
\text { Mark-up }\end{array}$ & Sector & $\begin{array}{c}\text { Contract } \\
\text { Won? }\end{array}$ & $\begin{array}{c}\text { Bid } \\
\text { Price }\end{array}$ \\
\hline 1 & 545.7 & 13.0 & B & yes & 616.7 & 56 & 762.1 & 13.5 & B & no & 865.2 \\
\hline 35 & 740.3 & 10.6 & B & yes & 818.6 & 57 & 431.1 & 19.2 & B & no & 513.8 \\
\hline 36 & 502.9 & 14.5 & $\mathrm{~B}$ & yes & 575.7 & 59 & 416.6 & 16.8 & B & no & 486.3 \\
\hline 46 & 605.1 & 15.0 & $\mathrm{~B}$ & yes & 695.9 & 69 & 648.6 & 15.3 & B & no & 747.6 \\
\hline 47 & 518.7 & 15.1 & B & yes & 597.2 & 71 & 593.7 & 9.4 & B & no & 649.5 \\
\hline 61 & 404.6 & 10.8 & B & yes & 448.3 & 76 & 765.2 & 8.4 & B & no & 829.6 \\
\hline 83 & 508.7 & 12.1 & B & yes & 570.4 & 77 & 495.0 & 15.3 & B & no & 570.9 \\
\hline 97 & 561.5 & 12.0 & B & yes & 629.1 & 80 & 717.1 & 11.9 & B & no & 802.6 \\
\hline 102 & 483.6 & 15.1 & B & yes & 556.4 & 84 & 619.5 & 8.9 & B & no & 674.8 \\
\hline 107 & 428.7 & 18.5 & B & yes & 508.0 & 85 & 565.8 & 15.0 & B & no & 650.4 \\
\hline 109 & 535.5 & 14.0 & B & yes & 610.5 & 88 & 546.6 & 6.4 & B & no & 581.7 \\
\hline 125 & 512.6 & 13.8 & B & yes & 583.2 & 89 & 415.7 & 14.1 & B & no & 474.3 \\
\hline
\end{tabular}




\begin{tabular}{|c|c|c|c|c|c|c|c|c|c|c|c|}
\hline $\mathbf{1 5 5}$ & 615.3 & 12.5 & B & yes & 692.2 & $\mathbf{1 1 2}$ & 536.1 & 13.5 & B & no & 608.8 \\
\hline $\mathbf{7}$ & 506.9 & 22.7 & B & no & 621.8 & $\mathbf{1 4 7}$ & 587.8 & 14.6 & B & no & 673.8 \\
\hline $\mathbf{1 0}$ & 523.9 & 8.6 & B & no & 568.7 & $\mathbf{1 5 2}$ & 797.0 & 8.3 & B & no & 863.1 \\
\hline $\mathbf{1 8}$ & 425.0 & 16.0 & B & no & 493.1 & $\mathbf{1 5 3}$ & 638.7 & 13.4 & B & no & 724.0 \\
\hline $\mathbf{2 4}$ & 452.8 & 15.2 & B & no & 521.8 & $\mathbf{1 6 0}$ & 434.9 & 10.4 & B & no & 480.2 \\
\hline $\mathbf{3 1}$ & 453.9 & 15.0 & B & no & 522.0 & & & & & & \\
\hline $\mathbf{4 0}$ & 593.9 & 11.6 & B & no & 662.7 & & & & & & \\
\hline $\mathbf{4 3}$ & 547.7 & 12.1 & B & no & 614.0 & & & & & & \\
\hline
\end{tabular}

Table 14. Summary of data properties (win and loss) for sector $B$

\begin{tabular}{|c|c|c|c|c|c|c|}
\hline \multirow{2}{*}{ Sector B } & \multicolumn{3}{|c|}{ Win } & \multicolumn{3}{|c|}{ Loss } \\
\hline & Estimated Cost & \%Mark-up & Bid price & Estimated Cost & \%Mark-up & Bid price \\
\hline Bids & \multicolumn{3}{|c|}{13} & \multicolumn{3}{|c|}{24} \\
\hline Mean & 535.6 & 13.6 & 607.9 & 561.5 & 13.2 & 633.4 \\
\hline St_dev & 85.52194123 & 2.127580957 & 91.76739005 & 115.7823192 & 3.778071774 & 121.7265507 \\
\hline St_dev ${ }^{2}$ & 7314.002431 & 4.526600729 & 8421.253877 & 13405.54543 & 14.27382633 & 14817.35316 \\
\hline $\mathbf{t}_{\alpha / 2}$ & \multicolumn{3}{|c|}{2.178812827} & \multicolumn{3}{|c|}{2.068657599} \\
\hline Confidence & 46.48940256 & 1.156544931 & 49.88440483 & 46.321724 & 1.511515741 & 48.69986823 \\
\hline Lower & 489.1 & 12.5 & 558 & 515.2 & 11.6 & 584.7 \\
\hline Upper & 582.1 & 14.8 & 657.7 & 607.8 & 14.7 & 682.1 \\
\hline Interval & $(489.1,582.1)$ & $(12.5,14.8)$ & $(558,657.7)$ & $(515.2,607.8)$ & $(11.6,14.7)$ & $(584.7,682.10)$ \\
\hline
\end{tabular}

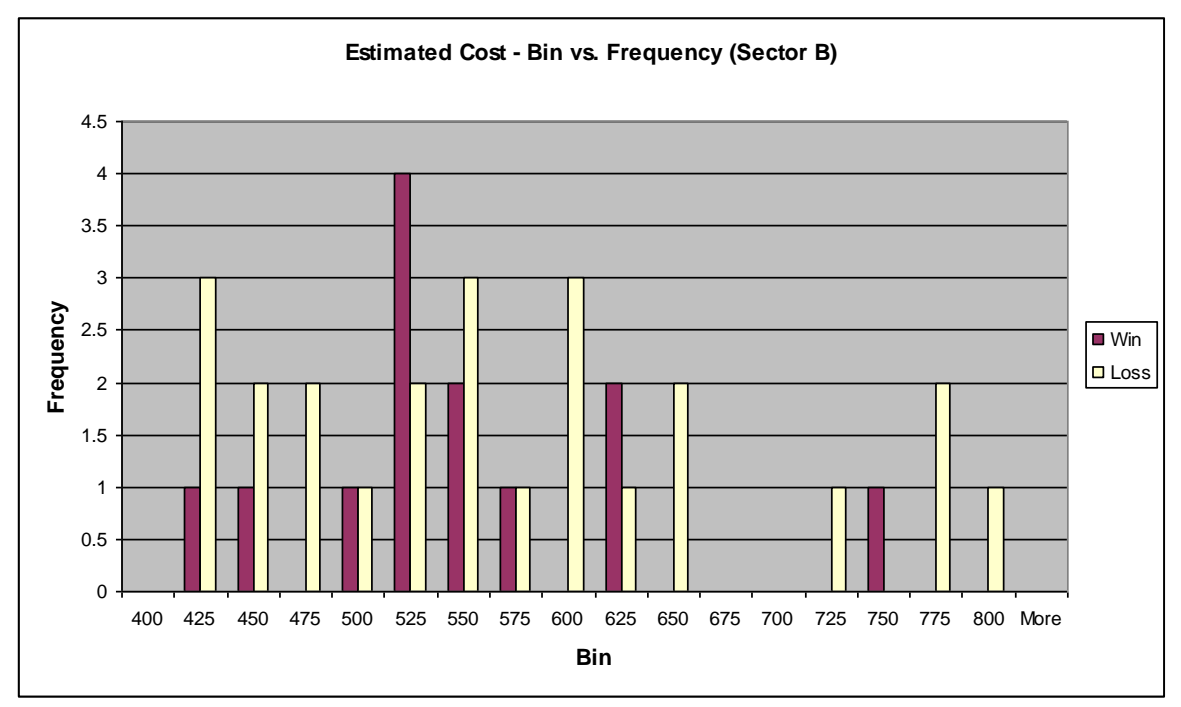

Figure 18. Estimated cost - bin vs. frequency (sector B). 


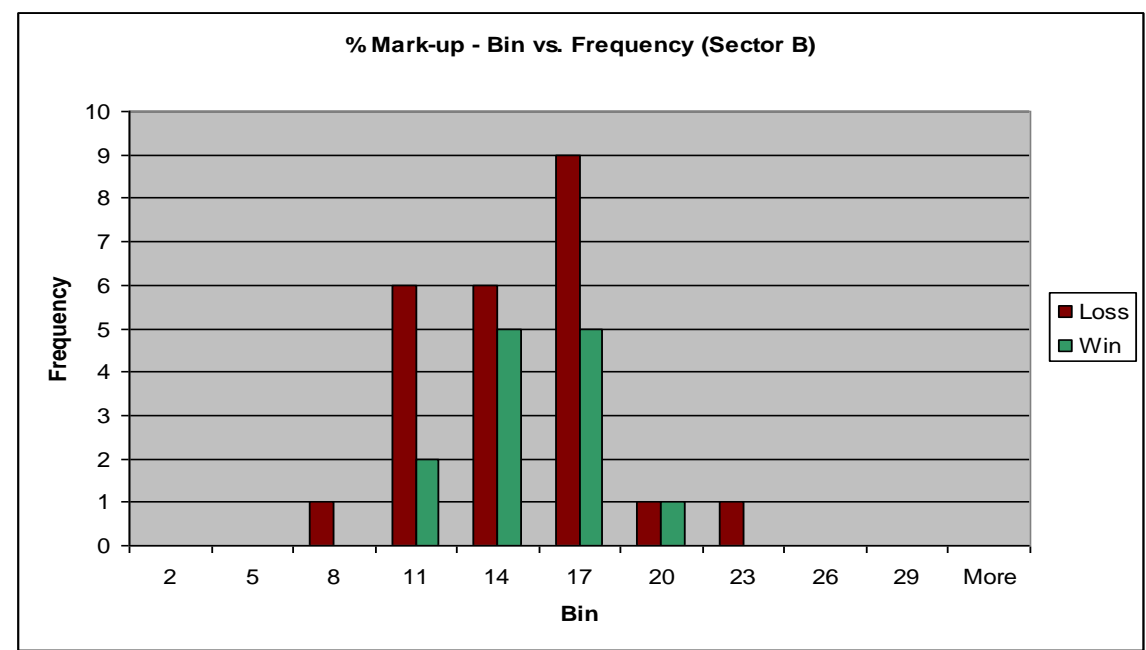

Figure 19. \% mark-up - bin vs. frequency (sector B).

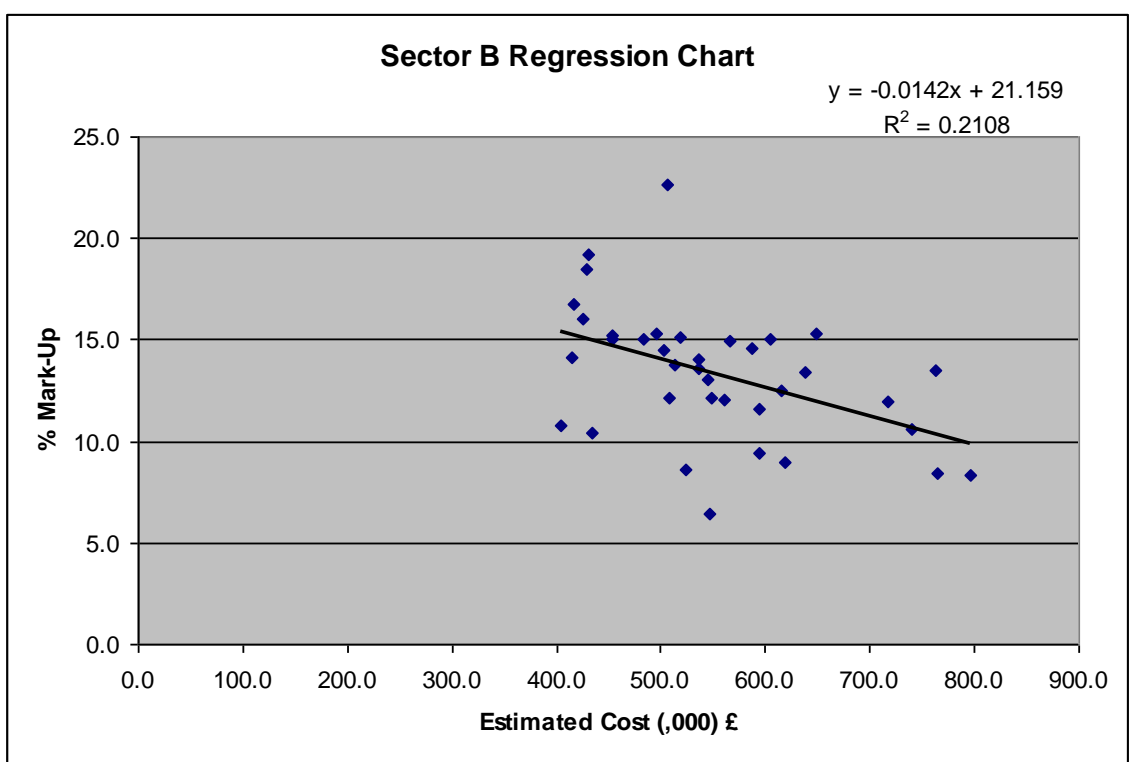

Figure 20. Sector B regression chart plot Estimated cost vs. \% mark-up

Table 15. Sector $B$ regression table being (a) summary output and (b) Anova

SUMMARY OUTPUT

\begin{tabular}{cc}
\hline \multicolumn{2}{c}{ Regression Statistics } \\
\hline Multiple R & 0.459077766 \\
R Square & 0.210752396 \\
Adjusted R Square & 0.188202464 \\
Standard Error & 2.944327471 \\
Observations & 37 \\
\hline
\end{tabular}

ANOVA

(b)

\begin{tabular}{lllll}
$d f$ & SS & MS & Significance $F$ \\
\hline
\end{tabular}


Journal of Advanced Research in Civil Engineering and Architecture, 2 (1):17-42, 2020

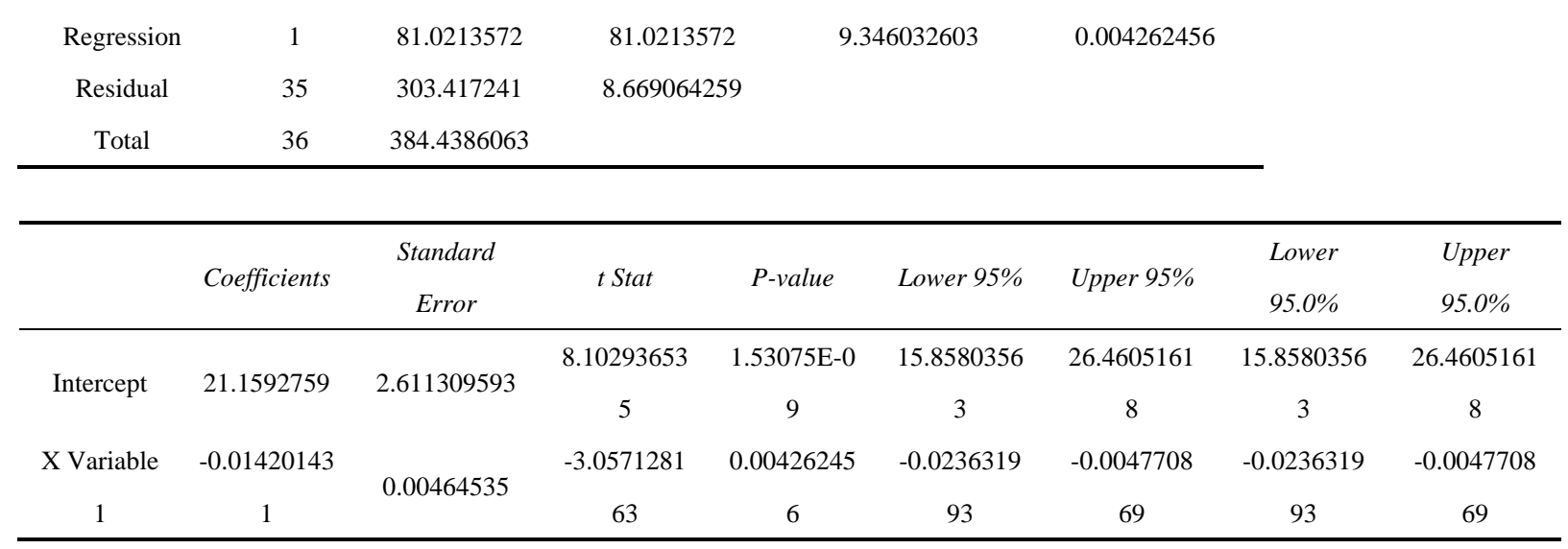

Table 16. t-test estimated cost - sector $B$ estimate win and loss

Estimated cost

Estimate B: Pass Fail

t-Test: Two-Sample Assuming Unequal Variances

\begin{tabular}{ccc}
\hline & Variable 1 & Variable 2 \\
\hline Mean & 535.623642 & 561.4751356 \\
Obsiance & 7314.002431 & 13405.54543 \\
Hypothesized Mean Difference & 13 & 24 \\
$\mathrm{df}$ & 0 & \\
$\mathrm{t}$ Stat & 31 & \\
$\mathrm{P}(\mathrm{T}<=\mathrm{t})$ one-tail & -0.77205453 & \\
$\mathrm{t}$ Critical one-tail & 0.222964149 & \\
$\mathrm{P}(\mathrm{T}<=\mathrm{t})$ two-tail & 1.695518742 & \\
$\mathrm{t}$ Critical two-tail & 0.445928298 & \\
\hline
\end{tabular}

Table 17. t-test $\%$ mark-up - sector $B$ estimate win and loss

$$
\% \text { Mark-up }
$$

Estimate B: Pass Fail

t-Test: Two-Sample Assuming Unequal Variances

\begin{tabular}{ccc}
\hline & Variable 1 & Variable 2 \\
\hline Mean & 13.61598014 & 13.15122385 \\
Variance & 4.526600729 & 14.27382633 \\
Observations & 13 & 24 \\
Hypothesized Mean Difference & 0 & \\
$\mathrm{df}$ & 35 & \\
$\mathrm{t}$ Stat & 0.478610911 & \\
$\mathrm{P}(\mathrm{T}<=\mathrm{t})$ one-tail & 0.317595945 & \\
$\mathrm{t}$ Critical one-tail & 1.68957244 & \\
$\mathrm{P}(\mathrm{T}<=\mathrm{t})$ two-tail & 0.635191889 & \\
$\mathrm{t}$ Critical two-tail & 2.030107915 & \\
\hline
\end{tabular}




\section{Appendix 3 (Sector C)}

Table 18. Set of data for sector $\mathrm{C}$ sorted according to contracts won and contracts loss

\begin{tabular}{|c|c|c|c|c|c|c|c|c|c|c|c|}
\hline $\begin{array}{c}\text { Bid } \\
\#\end{array}$ & Estimated Cost & $\%$ Mark-up & Sector & $\begin{array}{c}\text { Contract } \\
\text { Won? }\end{array}$ & Bid Price & $\begin{array}{c}\text { Bid } \\
\#\end{array}$ & $\begin{array}{c}\text { Estimated } \\
\text { Cost }\end{array}$ & $\begin{array}{c}\% \\
\text { Mark-up }\end{array}$ & Sector & $\begin{array}{c}\text { Contract } \\
\text { Won? }\end{array}$ & $\begin{array}{c}\text { Bid } \\
\text { Price }\end{array}$ \\
\hline 17 & 562.0 & 8.3 & $\mathrm{C}$ & yes & 608.8 & 67 & 513.2 & 13.9 & $\mathrm{C}$ & no & 584.4 \\
\hline 55 & 787.8 & 8.5 & $\mathrm{C}$ & yes & 854.6 & 70 & 542.4 & 20.4 & $\mathrm{C}$ & no & 653.2 \\
\hline 60 & 675.1 & 9.3 & $\mathrm{C}$ & yes & 737.9 & 81 & 912.2 & 10.1 & $\mathrm{C}$ & no & 1004.4 \\
\hline 91 & 922.4 & -0.7 & $\mathrm{C}$ & yes & 916.1 & 87 & 869.9 & 10.2 & $\mathrm{C}$ & no & 958.2 \\
\hline 118 & 772.8 & 16.8 & $\mathrm{C}$ & yes & 902.7 & 95 & 877.6 & 5.4 & $\mathrm{C}$ & no & 925.3 \\
\hline 127 & 729.3 & 8.5 & $\mathrm{C}$ & yes & 791.5 & 100 & 635.6 & 15.8 & $\mathrm{C}$ & no & 736.3 \\
\hline 133 & 922.2 & 1.4 & $\mathrm{C}$ & yes & 934.9 & 101 & 654.8 & 12.6 & $\mathrm{C}$ & no & 737.4 \\
\hline 138 & 643.5 & 14.1 & $\mathrm{C}$ & yes & 734.0 & 104 & 564.9 & 18.1 & $\mathrm{C}$ & no & 667.0 \\
\hline 2 & 771.2 & 9.2 & $\mathrm{C}$ & no & 842.2 & 113 & 683.9 & 14.3 & $\mathrm{C}$ & no & 781.5 \\
\hline 4 & 578.4 & 13.5 & $\mathrm{C}$ & no & 656.4 & 114 & 592.2 & 16.2 & $\mathrm{C}$ & no & 688.3 \\
\hline 5 & 619.7 & 15.9 & $\mathrm{C}$ & no & 717.9 & 116 & 691.3 & 14.3 & $\mathrm{C}$ & no & 790.4 \\
\hline 6 & 724.3 & 13.7 & $\mathrm{C}$ & no & 823.2 & 117 & 671.8 & 22.0 & $\mathrm{C}$ & no & 819.5 \\
\hline 12 & 988.3 & 6.0 & $\mathrm{C}$ & no & 1047.1 & 130 & 925.2 & 14.3 & $\mathrm{C}$ & no & 1057.5 \\
\hline 14 & 923.1 & 8.1 & $\mathrm{C}$ & no & 998.1 & 132 & 865.5 & 16.6 & $\mathrm{C}$ & no & 1009.2 \\
\hline 15 & 569.9 & 20.7 & $\mathrm{C}$ & no & 687.6 & 134 & 630.9 & 11.2 & $\mathrm{C}$ & no & 701.8 \\
\hline 20 & 669.4 & 10.0 & $\mathrm{C}$ & no & 736.5 & 137 & 956.4 & 7.9 & $\mathrm{C}$ & no & 1031.9 \\
\hline 26 & 996.5 & 6.1 & $\mathrm{C}$ & no & 1057.2 & 139 & 858.0 & 7.6 & $\mathrm{C}$ & no & 923.3 \\
\hline 34 & 694.3 & 9.3 & $\mathrm{C}$ & no & 758.8 & 142 & 650.8 & 18.0 & $\mathrm{C}$ & no & 768.1 \\
\hline 38 & 945.6 & 11.7 & $\mathrm{C}$ & no & 1056.4 & 144 & 767.0 & 8.8 & $\mathrm{C}$ & no & 834.7 \\
\hline 48 & 698.9 & 11.0 & $\mathrm{C}$ & no & 775.8 & 149 & 813.3 & 18.8 & $\mathrm{C}$ & no & 965.8 \\
\hline 52 & 549.0 & 12.1 & $\mathrm{C}$ & no & 615.2 & & & & & & \\
\hline
\end{tabular}

Table 19. Summary of properties of data for sector $C$

\begin{tabular}{|l|l|l|l|}
\hline Sector C & Estimated Cost & \%Mark Up & Bid Price \\
\hline Mean & 742 & 11.9 & 826.6 \\
\hline Std_dev & 142.1105 & 5.019588 & 139.9928 \\
\hline Minimum & 513.2 & -0.7 & 584.4 \\
\hline Maximum & 996.5 & 22 & 1057.5 \\
\hline Number & 41 & 41 & 41 \\
\hline Confidence & 43.4993062 & 1.5364705 & 14.7465 \\
\hline \% Pass Rate & 19.5122 & 19.5122 & 19.5122 \\
\hline Std_dev & 20195.39421 & 25.196264 & 19597.98 \\
\hline Number Won & 8 & 8 & 8 \\
\hline
\end{tabular}


Table 20. Summary of data properties (win and loss) for sector $C$

\begin{tabular}{|c|c|c|c|c|c|c|}
\hline \multirow{2}{*}{ Sector C } & \multicolumn{3}{|l|}{ Win } & \multicolumn{3}{|l|}{ Loss } \\
\hline & Estimated Cost & \%Mark-up & Bid price & Estimated Cost & \%Mark-up & Bid price \\
\hline Bids & \multicolumn{3}{|l|}{8} & \multicolumn{3}{|l|}{33} \\
\hline Mean & 751.9 & 8.3 & 810.1 & 739.6 & 12.8 & 830.6 \\
\hline St_dev & 127.6373231 & 5.799339164 & 112.9038414 & 147.1391015 & 4.466394039 & 147.0510052 \\
\hline St_dev ${ }^{2}$ & 16291.28625 & 33.63233474 & 12747.27739 & 21649.9152 & 19.94867571 & 21623.99812 \\
\hline $\mathbf{t}_{\boldsymbol{\alpha} / 2}$ & \multicolumn{3}{|l|}{2.364624251} & \multicolumn{3}{|l|}{2.036933334} \\
\hline Confidence & 88.4465271 & 4.018663163 & 78.23693276 & 50.2017921 & 1.523870832 & 50.17173487 \\
\hline Lower & 663.4 & 4.3 & 731.8 & 689.4 & 11.3 & 780.5 \\
\hline Upper & 840.3 & 12.3 & 888.3 & 789.8 & 14.4 & 880.8 \\
\hline Interval & $(663.4,840.3)$ & $(4.3,12.3)$ & $(731.8,888.3)$ & $(689.4,789.8)$ & $(11.3,14.4)$ & $(780.5,880.8)$ \\
\hline
\end{tabular}

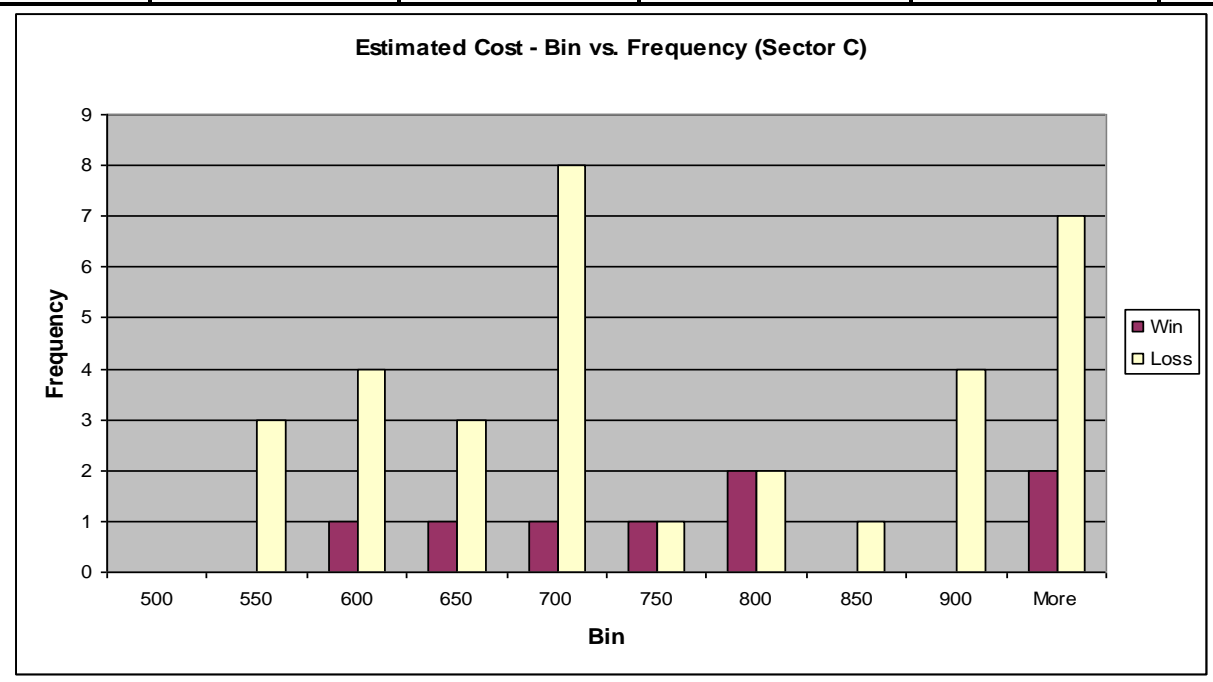

Figure 21. Estimated cost - bin vs. frequency (sector C)

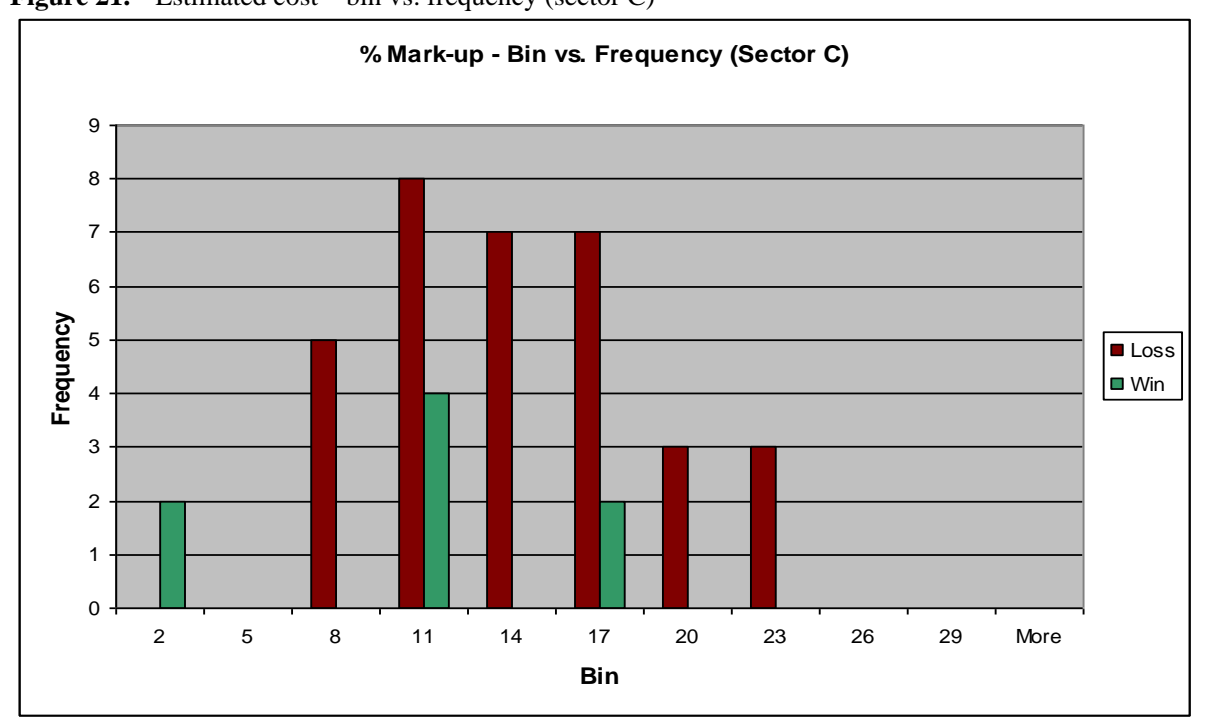

Figure 22. $\%$ mark-up - bin vs. frequency (sector C) 


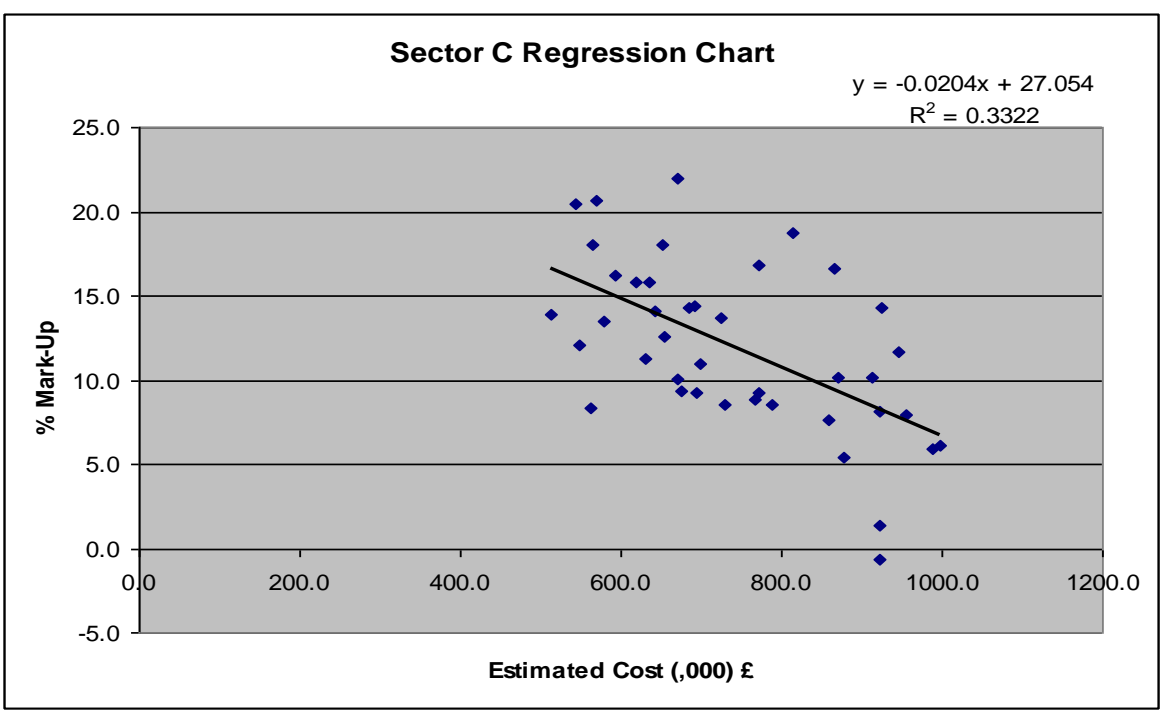

Figure 23. Sector $C$ regression chart plot Estimated cost vs. \% mark-up

Table 21. Sector $C$ regression table being (a) summary output and (b) Anova

(a)

\section{SUMMARY OUTPUT}

\begin{tabular}{ll}
\hline Regression Statistics & \\
\hline Multiple R & 0.576346356 \\
R Square & 0.332175123 \\
Adjusted R Square & 0.315051408 \\
Standard Error & 4.154292328 \\
Observations & 41 \\
\hline
\end{tabular}

(b)

ANOVA

\begin{tabular}{llllll}
\hline & $d f$ & $S S$ & $M S$ & $F$ & Significance $F$ \\
\hline Regression & 1 & 334.7828675 & 334.7828675 & 19.39854327 & $8.02809 \mathrm{E}-05$ \\
Residual & 39 & 673.067645 & 17.25814474 & & \\
Total & 40 & 1007.850513 & & & \\
\hline
\end{tabular}

\begin{tabular}{lllllllll}
\hline & Coefficients & Standard Error & $t$ Stat & P-value & Lower 95\% & Upper 95\% & Lower 95.0\% & Upper 95.0\% \\
\hline Intercept & 27.05407619 & 3.490268188 & 7.751288651 & $2.03908 \mathrm{E}-09$ & 19.99434249 & 34.1138099 & 19.99434249 & 34.1138099 \\
X Variable 1 & -0.020357552 & 0.004622118 & -4.404377739 & $8.02809 \mathrm{E}-05$ & -0.029706668 & -0.011008437 & -0.029706668 & -0.011008437 \\
\hline
\end{tabular}

Table 22. t-test estimated cost - sector $C$ estimate win and loss

\section{Estimated cost}

\section{Estimate C: Pass Fail}

t-Test: Two-Sample Assuming Unequal Variances

\begin{tabular}{lll}
\hline & Variable 1 & Variable 2 \\
\hline Mean & 751.8872966 & 739.5563557 \\
Variance & 16291.28625 & 21649.9152 \\
Observations & 8 & 33
\end{tabular}




\begin{tabular}{|c|c|c|}
\hline Hypothesized Mean Difference & 0 & \\
\hline $\mathrm{df}$ & 12 & \\
\hline t Stat & 0.237640728 & \\
\hline $\mathrm{P}(\mathrm{T}<=\mathrm{t})$ one-tail & 0.40808436 & \\
\hline t Critical one-tail & 1.782287548 & \\
\hline $\mathrm{P}(\mathrm{T}<=\mathrm{t})$ two-tail & 0.816168719 & \\
\hline t Critical two-tail & 2.178812827 & \\
\hline$\%$ Mark-up & & \\
\hline Estimate C: Pass Fail & & \\
\hline t-Test: Two-Sample Assuming L & & \\
\hline & Variable 1 & Variable 2 \\
\hline Mean & 8.276881886 & 12.83987881 \\
\hline Variance & 33.63233474 & 19.94867571 \\
\hline Observations & 8 & 33 \\
\hline Hypothesized Mean Difference & 0 & \\
\hline $\mathrm{df}$ & 9 & \\
\hline t Stat & -2.080861793 & \\
\hline $\mathrm{P}(\mathrm{T}<=\mathrm{t})$ one-tail & 0.033585639 & \\
\hline t Critical one-tail & 1.833112923 & \\
\hline $\mathrm{P}(\mathrm{T}<=\mathrm{t})$ two-tail & 0.067171278 & \\
\hline t Critical two-tail & 2.262157158 & \\
\hline
\end{tabular}

\section{Appendix 4 (Sector D)}

Table 24. Set of data for sector D sorted according to contracts won and contracts loss

\begin{tabular}{|c|c|c|c|c|c|c|c|c|c|c|c|}
\hline $\begin{array}{l}\text { Bid } \\
\#\end{array}$ & Estimated Cost & $\%$ Mark-up & Sector & $\begin{array}{l}\text { Contract } \\
\text { Won? }\end{array}$ & Bid Price & $\begin{array}{l}\text { Bid } \\
\#\end{array}$ & $\begin{array}{l}\text { Estimated } \\
\text { Cost }\end{array}$ & $\begin{array}{l}\% \\
\text { Mark-up }\end{array}$ & Sector & $\begin{array}{l}\text { Contract } \\
\text { Won? }\end{array}$ & $\begin{array}{l}\text { Bid } \\
\text { Price }\end{array}$ \\
\hline 3 & 477.7 & 16.1 & $\mathrm{D}$ & yes & 554.7 & 58 & 346.3 & 24.4 & $\mathrm{D}$ & no & 430.6 \\
\hline 19 & 426.4 & 18.9 & $\mathrm{D}$ & yes & 506.9 & 62 & 333.5 & 24.4 & $\mathrm{D}$ & no & 414.8 \\
\hline 22 & 563.4 & 15.3 & $\mathrm{D}$ & yes & 649.5 & 73 & 446.5 & 21.5 & $\mathrm{D}$ & no & 542.4 \\
\hline 49 & 545.6 & 22.7 & $\mathrm{D}$ & yes & 669.4 & 74 & 451.1 & 20.3 & $\mathrm{D}$ & no & 542.8 \\
\hline 64 & 535.3 & 19.0 & $\mathrm{D}$ & yes & 637.1 & 75 & 347.0 & 27.4 & $\mathrm{D}$ & no & 442.1 \\
\hline 65 & 588.0 & 17.1 & $\mathrm{D}$ & yes & 688.6 & 82 & 309.4 & 17.4 & $\mathrm{D}$ & no & 363.1 \\
\hline 86 & 383.5 & 16.2 & $\mathrm{D}$ & yes & 445.5 & 92 & 389.4 & 13.3 & $\mathrm{D}$ & no & 441.1 \\
\hline 108 & 487.8 & 11.3 & $\mathrm{D}$ & yes & 542.9 & 93 & 522.1 & 24.3 & $\mathrm{D}$ & no & 648.9 \\
\hline 115 & 547.2 & 14.5 & $\mathrm{D}$ & yes & 626.5 & 98 & 363.1 & 16.0 & $\mathrm{D}$ & no & 421.0 \\
\hline 120 & 275.1 & 21.9 & $\mathrm{D}$ & yes & 335.4 & 99 & 453.9 & 19.6 & $\mathrm{D}$ & no & 543.0 \\
\hline 124 & 481.5 & 13.6 & $\mathrm{D}$ & yes & 547.1 & 105 & 595.1 & 16.5 & $\mathrm{D}$ & no & 693.2 \\
\hline 11 & 592.0 & 11.9 & $\mathrm{D}$ & no & 662.4 & 119 & 566.1 & 21.0 & $\mathrm{D}$ & no & 684.7 \\
\hline 23 & 473.1 & 17.6 & $\mathrm{D}$ & no & 556.6 & 122 & 438.0 & 15.0 & $\mathrm{D}$ & no & 503.9 \\
\hline 28 & 383.4 & 12.8 & $\mathrm{D}$ & no & 432.5 & 128 & 366.4 & 18.3 & $\mathrm{D}$ & no & 433.5 \\
\hline 29 & 359.7 & 20.9 & $\mathrm{D}$ & no & 434.9 & 129 & 355.5 & 24.3 & $\mathrm{D}$ & no & 441.8 \\
\hline
\end{tabular}




\begin{tabular}{|l|l|l|l|l|l|l|l|l|l|l|l|}
\hline $\mathbf{3 2}$ & 291.9 & 21.6 & $\mathrm{D}$ & no & 355.0 & $\mathbf{1 3 1}$ & 402.2 & 14.6 & $\mathrm{D}$ & no & 460.8 \\
\hline $\mathbf{3 3}$ & 301.2 & 24.0 & $\mathrm{D}$ & no & 373.5 & $\mathbf{1 4 0}$ & 315.6 & 25.0 & $\mathrm{D}$ & no & 394.5 \\
\hline $\mathbf{3 7}$ & 531.1 & 21.9 & $\mathrm{D}$ & no & 647.2 & $\mathbf{1 4 3}$ & 550.6 & 9.5 & $\mathrm{D}$ & no & 602.9 \\
\hline $\mathbf{3 9}$ & 463.8 & 19.5 & $\mathrm{D}$ & no & 554.3 & $\mathbf{1 4 6}$ & 250.8 & 20.9 & $\mathrm{D}$ & no & 303.2 \\
\hline $\mathbf{4 4}$ & 421.0 & 22.6 & $\mathrm{D}$ & no & 516.1 & $\mathbf{1 5 1}$ & 377.4 & 16.5 & $\mathrm{D}$ & no & 439.6 \\
\hline $\mathbf{4 5}$ & 595.1 & 13.6 & $\mathrm{D}$ & no & 675.9 & $\mathbf{1 5 6}$ & 361.7 & 15.8 & $\mathrm{D}$ & no & 418.9 \\
\hline $\mathbf{5 4}$ & 463.8 & 20.4 & $\mathrm{D}$ & no & 558.4 & & & & & & \\
\hline
\end{tabular}

Table 25. Summary of data properties (win and loss) for sector $D$

\begin{tabular}{|c|c|c|c|c|c|c|}
\hline \multirow{2}{*}{ Sector D } & \multicolumn{3}{|l|}{ Win } & \multicolumn{3}{|l|}{ Loss } \\
\hline & Estimated Cost & \%Mark-up & Bid price & Estimated Cost & \%Mark-up & Bid price \\
\hline Bids & \multicolumn{3}{|l|}{11} & \multicolumn{3}{|l|}{32} \\
\hline Mean & 482.9 & 17 & 563.9 & 419.3 & 19.1 & 497.9 \\
\hline St_dev & 92.0034471 & 3.442504276 & 106.6 & 95.72726943 & 4.427500027 & 107.3865662 \\
\hline St_dev ${ }^{2}$ & 8464.634279 & 11.85083569 & 11357.40136 & 9163.710113 & 19.60275649 & 11531.87461 \\
\hline $\mathbf{t}_{\alpha / 2}$ & \multicolumn{3}{|l|}{2.228138842} & \multicolumn{3}{|l|}{2.039513438} \\
\hline Confidence & 54.36956369 & 2.03435264 & 62.97834376 & 33.1671972 & 1.534022305 & 37.20686321 \\
\hline Lower & 428.5 & 14.9 & 501 & 386.1 & 17.6 & 460.7 \\
\hline Upper & 537.2 & 19 & 626.9 & 452.5 & 20.7 & 535.1 \\
\hline Interval & $(428.5,537.2)$ & $(14.9,19)$ & $(501,626.9)$ & $(386.1,452.5)$ & $(17.6,20.7)$ & $(460.7,535.1)$ \\
\hline
\end{tabular}

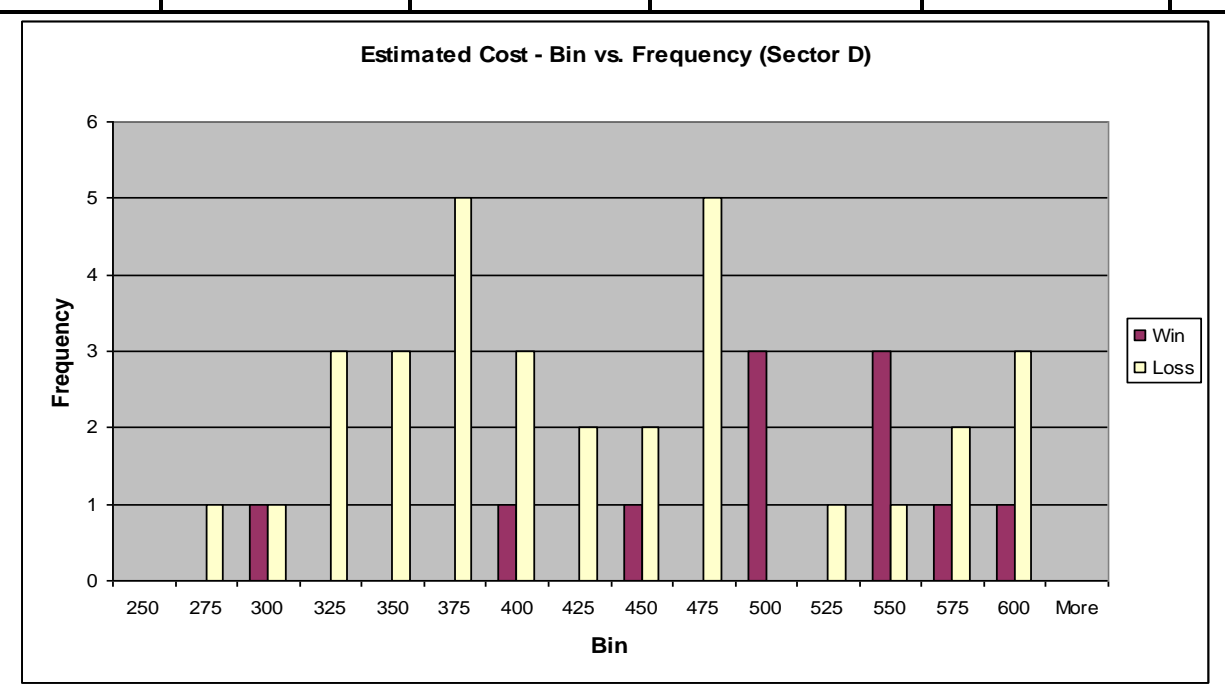

Figure 24. Estimated cost - bin vs. frequency (sector D) 


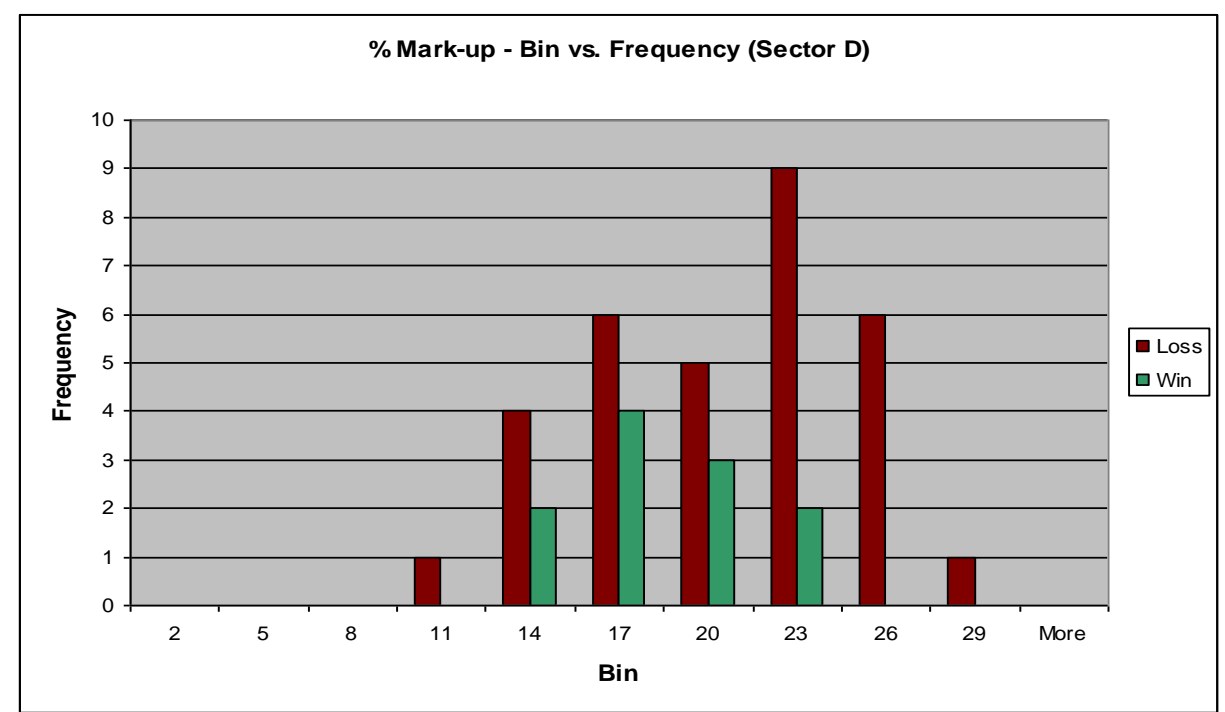

Figure 25. \% mark-up - bin vs. frequency (sector D)

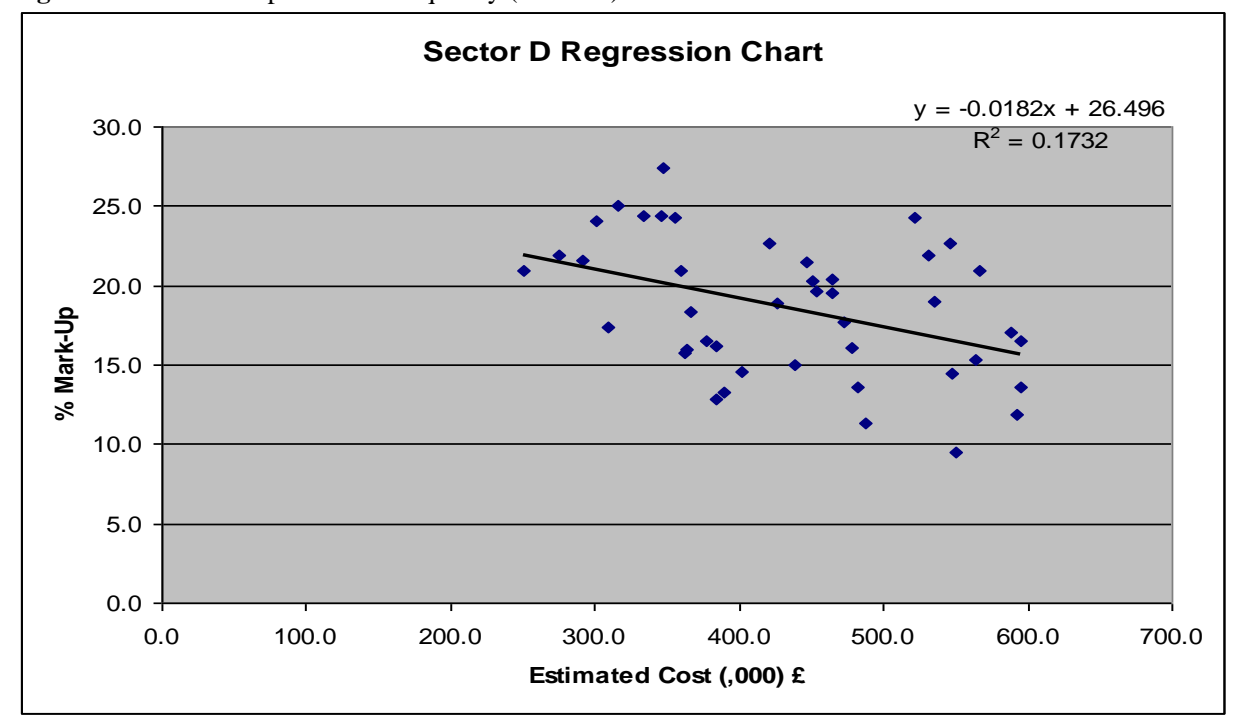

Figure 26. Sector $D$ regression chart plot estimated cost vs. \% mark-up

Table 26. Sector $D$ regression table being (a) summary output and (b) Anova

(a)

SUMMARY OUTPUT

\begin{tabular}{ll}
\hline Regression Statistics & \\
\hline Multiple R & 0.416169721 \\
R Square & 0.173197237 \\
Adjusted R Square & 0.153031316 \\
Standard Error & 3.928440235 \\
Observations & 43 \\
\hline
\end{tabular}

(b)

ANOVA

\begin{tabular}{llllll}
\hline & $d f$ & $S S$ & $M S$ & $F$ & Significance $F$ \\
\hline Regression & 1 & 132.5449537 & 132.5449537 & 8.588610285 & 0.005507565
\end{tabular}




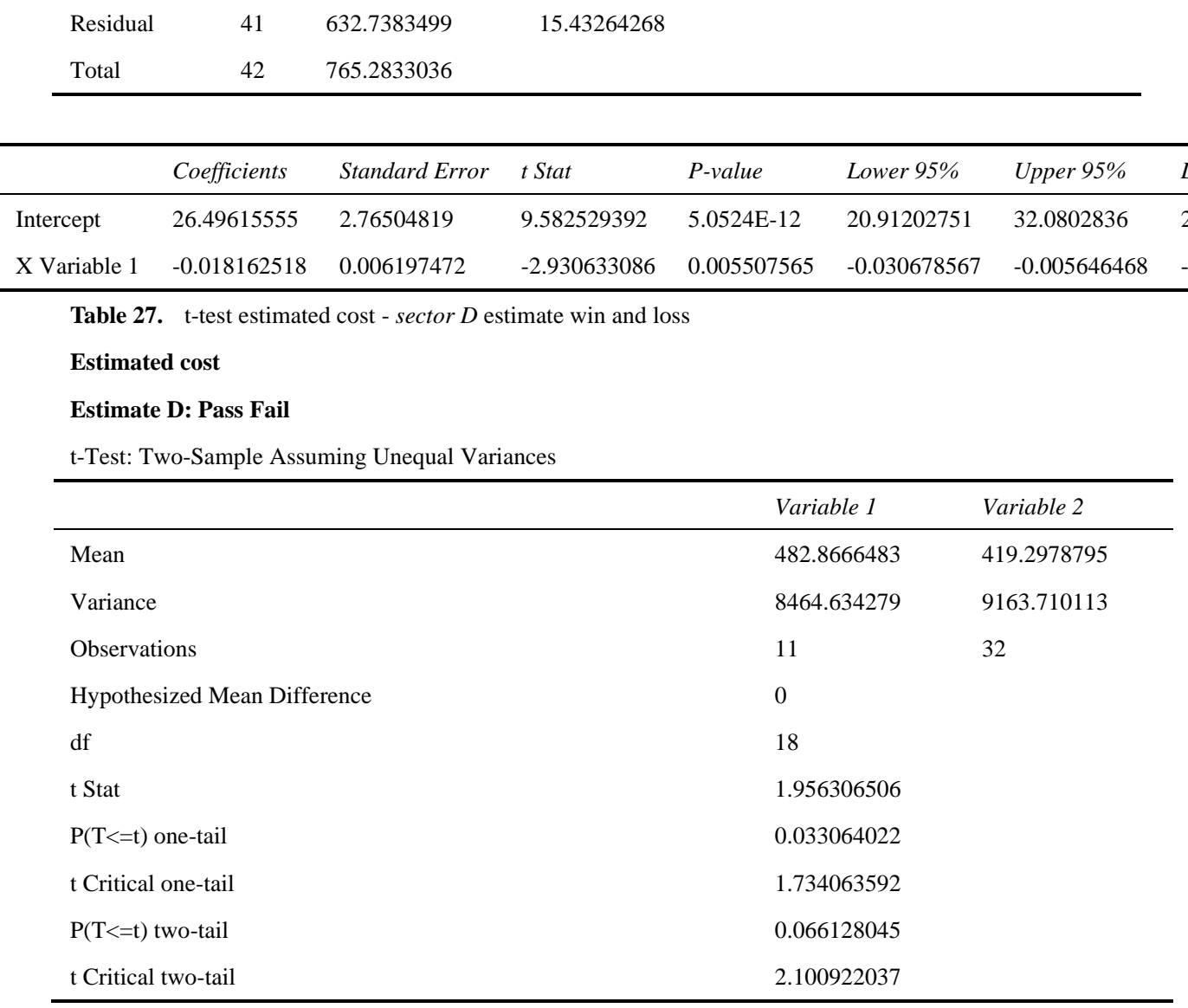

Table 28. t-test \% mark-up - sector $D$ estimate win and loss

$\%$ Mark-up

Estimate D: Pass Fail

t-Test: Two-Sample Assuming Unequal Variances

\begin{tabular}{|c|c|c|}
\hline & Variable 1 & Variable 2 \\
\hline Mean & 16.95909369 & 19.14430243 \\
\hline Variance & 11.85083569 & 19.60275649 \\
\hline Observations & 11 & 32 \\
\hline Hypothesized Mean Difference & 0 & \\
\hline df & 22 & \\
\hline t Stat & -1.680962205 & \\
\hline $\mathrm{P}(\mathrm{T}<=\mathrm{t})$ one-tail & 0.053457267 & \\
\hline t Critical one-tail & 1.717144335 & \\
\hline $\mathrm{P}(\mathrm{T}<=\mathrm{t})$ two-tail & 0.106914534 & \\
\hline t Critical two-tail & 2.073873058 & \\
\hline
\end{tabular}

